\title{
Docosahexaenoic acid (DHA) effects on proliferation and steroidogenesis of bovine granulosa cells
}

Virginie Maillard ${ }^{1,2^{*} \dagger}$, Alice Desmarchais ${ }^{1 \dagger}$, Maeva Durcin ${ }^{1}$, Svetlana Uzbekova ${ }^{1}$ and Sebastien Elis ${ }^{1}$

\begin{abstract}
Background: Docosahexaenoic acid (DHA) is a $n-3$ polyunsaturated fatty acid (PUFA) belonging to a family of biologically active fatty acids (FA), which are known to have numerous health benefits. N-3 PUFAs affect reproduction in cattle, and notably directly affect follicular cells. In terms of reproduction in cattle, n-3 PUFA-enriched diets lead to increased follicle size or numbers.

Methods: The objective of the present study was to analyze the effects of DHA (1, 10,20 and $50 \mu \mathrm{M})$ on proliferation and steroidogenesis (parametric and/or non parametric (permutational) ANOVA) of bovine granulosa cells in vitro and mechanisms of action through protein expression (Kruskal-Wallis) and signaling pathways (non parametric ANOVA) and to investigate whether DHA could exert part of its action through the free fatty acid receptor 4 (FFAR4).
\end{abstract}

Results: DHA (10 and $50 \mu \mathrm{M}$ ) increased granulosa cell proliferation and DHA $10 \mu \mathrm{M}$ led to a corresponding increase in proliferating cell nuclear antigen (PCNA) expression level. DHA also increased progesterone secretion at 1, 20 and $50 \mu \mathrm{M}$, and estradiol secretion at 1,10 and $20 \mu \mathrm{M}$. Consistent increases in protein levels were also reported for the steroidogenic enzymes, cytochrome P450 family 11 subfamily A member 1 (CYP11A1) and hydroxy-delta-5-steroid dehydrogenase, 3 beta- and steroid delta-isomerase 1 (HSD3B1), and of the cholesterol transporter steroidogenic acute regulatory protein (StAR), which are necessary for production of progesterone or androstenedione. FFAR4 was expressed in all cellular types of bovine ovarian follicles, and in granulosa cells it was localized close to the cellular membrane. TUG-891 treatment (1 and 50 MM), a FFAR4 agonist, increased granulosa cell proliferation and MAPK14 phosphorylation in a similar way to that observed with DHA treatment. However, TUG-891 treatment (1, 10 and $50 \mu \mathrm{M})$ showed no effect on progesterone or estradiol secretion.

Conclusions: These data show that DHA stimulated proliferation and steroidogenesis of bovine granulosa cells and led to MAPK14 phosphorylation. FFAR4 involvement in DHA effects requires further investigation, even if our data might suggest FFAR4 role in DHA effects on granulosa cell proliferation. Other mechanisms of DHA action should be investigated as the steroidogenic effects seemed to be independent of FFAR4 activation.

Keywords: Bovine, Gene expression, Lipid, N-3 PUFA, DHA, Folliculogenesis, MAPK, AKT, AMPK, Signaling pathways, Free fatty acid receptor 4 (FFAR4)

\footnotetext{
* Correspondence: virginie.maillard@inra.fr

${ }^{\dagger}$ Equal contributors

'UMR PRC, CNRS, IFCE, INRA, Université de Tours, 37380 Nouzilly, France

${ }^{2}$ INRA Centre Val de Loire, Physiologie de la Reproduction et des

Comportements, 37380 Nouzilly, France
}

(c) The Author(s). 2018 Open Access This article is distributed under the terms of the Creative Commons Attribution 4.0 International License (http://creativecommons.org/licenses/by/4.0/), which permits unrestricted use, distribution, and reproduction in any medium, provided you give appropriate credit to the original author(s) and the source, provide a link to the Creative Commons license, and indicate if changes were made. The Creative Commons Public Domain Dedication waiver (http://creativecommons.org/publicdomain/zero/1.0/) applies to the data made available in this article, unless otherwise stated. 


\section{Background}

N-3 polyunsaturated fatty acids (PUFAs) belong to a family of biologically active fatty acids (FAs) and are known to have numerous health benefits [1]. The most well-known members are alpha-linolenic acid (ALA), eicosapentaenoic acid (EPA) and docosahexaenoic acid (DHA). These are essential FAs, as mammals cannot produce ALA, the precursor of n-3 PUFA. Furthermore, DHA, the longest-chain member of this family, has a 22carbon chain (C22:6) and can theoretically be produced from shorter-chain members of this family. As the efficiency of the desaturation reaction is low, the most extensive source of DHA is the diet, cold-water fish in particular [2, 3]. DHA is reported to exert pleiotropic effects at both central and peripheral levels, including the brain, heart and immune system [4-6].

Among their physiological roles, n-3 PUFAs affect reproduction in cattle $[7,8]$. The feeding of diets supplemented with n-3 PUFAs (enriched in ALA) was shown to increase calving rate in dairy cows [9-11]. At the uterus level, n-3 PUFAs reduced prostaglandin F2 alpha (PGF2 $\alpha$ ) secretion from endometrial cells [12-15]. Moreover, n-3 PUFA dietary supplement in cows was reported to exert effects at the ovarian level. Indeed, a n-3 PUFA-enriched diet led to an increased cleavage rate or a trend to increased blastocyst rate after in vivo maturation $[16,17]$ and n-3 PUFA supplementation during in vitro maturation also led to increased blastocyst rates $[18,19]$. In addition, dietary ALA supplementation led to an increase in the size of the pre-ovulatory follicles [9], in number of total follicles [16] or small follicles [17], to larger corpus luteum size and higher plasma progesterone levels [20, 21]. Dietary fish oil supplementation, containing both EPA and DHA, also led to an increased number of large follicles [11]. Dietary DHA improved resumption of estrous cyclicity and pregnancy at first artificial insemination [22]. These data suggest that n-3 PUFAs could favorably affect folliculogenesis by having direct effects on follicular cells, in addition to the already described effects on the oocyte. Nevertheless, several studies reported no effect of n-3 PUFA diet on female reproduction [21, 23], or even a deleterious effect leading to a more unfavorable uterine environment for sustaining pregnancies and reduced fertility in cows [24].

There are several mechanisms by which n-3 PUFAs could exhibit multiple physiological roles in organism development and diseases [25]: indirect actions on cells by influencing metabolite, hormone concentration, or other factors as oxidation of LDL and oxidative stress, direct actions on cells via receptors, sensors or cell membrane fatty acid composition (membrane order, lipid rafts, etc.) (reviewed in [26]). Most of the studies of n-3 PUFA mechanisms concern the inflammatory process [27]. Indeed, n-3 PUFAs were shown to affect cytokine expression, especially inflammatory cytokines (TNF, IL-1 $\beta$, IL-6 and IL-8), and to simultaneously help produce inflammatory resolving metabolites (resolvins, protectins, maresins) [26, 28]. Feeding with a n-3 PUFAenriched diet results in the membrane lipid composition being enriched in n-3 PUFA. Eicosanoids (prostaglandins, leucotrienes, thromboxanes and lipoxins) produced from n-3 PUFAs (for example, 3-series prostaglandins) are therefore increased and, conversely, eicosanoids produced from arachidonic acid (for example, 2-series prostaglandins) are reduced [28]. This decrease in 2-series prostaglandins induced a less inflammatory environment because 3-series prostaglandins are less inflammatory [29]. N-3 PUFAs were also reported to act through intracellular sensors such as peroxisome proliferator-activated receptors (PPARs) and nuclear factor kappa B and thus to modulate their target gene expression [26]. By affecting the membrane lipid composition, n-3 PUFAs are also able to increase membrane fluidity and to promote lipid raft formation and organization (reviewed in [30]), and therefore signaling pathways. N-3 PUFAs are also reported to act through free fatty acid receptors, FFAR1 and FFAR4, located in the membrane and activate their signaling pathways [31]. Indeed, FFAR4 can modulate signaling of mitogen-activated protein kinases MAPK1/3 (alias ERK 1/2) and MAPK14 (alias p38), and protein kinase B (Akt) [32, 33], which are already known to be involved in bovine granulosa cell (GC) proliferation and steroidogenesis [34-38].

In the present study, we choose to focus solely on DHA. Indeed, recent in vivo studies focused on algae oil supplementation, containing mainly DHA and no EPA (substitute of fish oil which does not exhibit the limitation of fish oil: limited resources and competition with human diet) [22, 39, 40]. Studying solely DHA effects is therefore a relevant step to understand its mechanism of action granulosa cells. We hypothesize that DHA could stimulate steroidogenesis in bovine GC and that it could exert part of its activity through the membrane receptor, FFAR4. The objective of the present study was therefore to examine the effects of DHA on proliferation and steroidogenesis of bovine GCs. We then investigated FFAR4 expression in GCs and reported its expression in ovarian follicles and in GCs. We thus investigated whether supplementation of the culture medium with a FFAR4 agonist, TUG-891 [41], could reproduce the effects of DHA in GCs. Treatment with DHA and TUG-891 was performed during GC culture, followed by examination of cell proliferation, progesterone and estradiol secretion, gene and protein expression, and signaling pathways.

\section{Methods}

Ethics

No experiments with living animals were performed. 


\section{Chemicals and antibody}

Customized anti-FFAR4 antibody was produced from a rabbit immunized against a peptide designed from the second extracellular loop (179-194 amino acids) of the bovine sequence (Accession number: NP_001315586.1). Serum from immunized rabbit underwent affinity purification and antibody concentration was measured by enzyme-linked immunosorbent assay (ELISA; Agro-Bio, La Ferté SaintAubin, France). This customized antibody enabled detection of a $42 \mathrm{kDa}$ band by western blot in lung tissue extract (Additional file 1: Figure S1). Lung tissue was used to validate the antibody, as in other species, namely mice and humans, the level of expression of FFAR4 protein is reported to be higher in this tissue than in other tissues, such as adipose tissue, intestine and liver [42].

DHA was obtained from Sigma-Aldrich (Saint Quentin Fallavier, France) and TUG-891 from Tocris (BioTechne Europe, Lille, France). Unless otherwise stated in the text, all other chemicals were obtained from SigmaAldrich (Saint Quentin Fallavier, France). Primary antibodies used are indicated in Additional file 2: Table S1. Horseradish peroxidase (HRP)-conjugated antirabbit and anti-mouse were purchased from Perkin Elmer (Courtaboeuf, France) and biotinylated horse anti-mouse and anti-rabbit IgG were from Vector Laboratories (Clinisciences, Nanterre, France). Alexa Fluor 488-conjugated donkey anti-rabbit IgG was purchased from Jackson ImmunoResearch (Newmarket, United Kingdom). Dimethyl sulfoxide (DMSO) 1/2000 was used as the control treatment as it is used as a solvent for DHA and TUG-891.

\section{Biological material}

Ovarian cortex were carefully dissected from 5 bovine ovaries collected from a local slaughterhouse. Theca cells were retrieved from healthy follicles of 5 bovine ovaries (local slaughterhouse): once the follicle is carefully dissected and opened, the inside of the follicle is gently scraped and washed in PBS to remove granulosa cells and cumulus-oocyte complex. Cumulus cells (without oocyte) were recovered as previously described [19] from 20 ovaries, briefly cumulus-oocyte complexes were sorted out after follicular punctures and oocytes were dissociated from cumulus cells by mechanical aspiration and removed. GCs were collected according the same protocol as when performing cell culture experiment (described in the following section). In the case of GC culture, antral follicles with a diameter of 2 to $6 \mathrm{~mm}$ were used. Ovaries exhibiting very large corpora lutea were excluded from the samples to avoid contamination of our granulosa cell samples from growing follicles with luteinized granulosa cells (originating from these corpora lutea) during ovary punctures. Lung tissue was collected from one cow (local slaughterhouse).

\section{Isolation and culture of granulosa cells}

Follicles from bovine ovaries were punctured using an $18 \mathrm{G}$ needle linked to a vacuum pump and a $50-\mathrm{mL}$ falcon tube, enabling the collection of follicular fluid which contained GCs. GCs were then washed in modified McCoy's 5A serum-free medium containing: Lglutamine (3 mM), HEPES (20 mM; pH 7.6), bovine serum albumin (BSA; essentially fatty acid free; $0.1 \%$ ), penicillin-streptomycin $\left(120 \times 10^{3} \mathrm{UI} / \mathrm{L}\right.$ penicillin; $120 \mathrm{mg} / \mathrm{L}$ streptomycin), amphotericin B $(50 \mu \mathrm{g} / \mathrm{L})$, bovine insulin $(1.74 \mathrm{nM})$, bovine apo-transferrin $(5 \mathrm{mg} /$ L), selenium $(0.12 \mu \mathrm{M})$ and 4-androsten-11 $\beta$-ol-3,17dione $(96 \mathrm{nM})$. After centrifugation and washes in medium, suspended cells were dropped off on a Percoll density medium (50\% Percoll, 50\% medium) and GCs were purified by centrifugation (300 g). Recovered GCs were incubated in serum-free modified McCoy's 5A medium in the appropriate cell density and plates according to the assays as described below. From the beginning of the culture, cells were cultured in the presence or absence of test reagents for different durations depending on the biological function of interest. Cultures were performed in a water-saturated atmosphere containing $5 \% \mathrm{CO}_{2}$ in air at $38^{\circ} \mathrm{C}$. The use of culture media without fetal bovine serum and a short culture duration limited the differentiation of GCs, which retained the round shape exhibited in vivo. Under the culture conditions used in this experiment, GCs still exhibited steroidogenic activity and were able to proliferate. The Additional file 3: Figure S2 presents the experiment design of the present work.

\section{Immunohistochemistry}

Bovine ovaries were embedded in paraffin and serially sectioned at a thickness of $7 \mu \mathrm{m}$ using a microtome. Adjacent sections were deparaffinized in toluene, rehydrated and incubated in antigen unmasking solution (1\% in water; Vector Laboratories) for $2 \mathrm{~min}$ in a microwave $(850 \mathrm{~W})$, left to cool for $1 \mathrm{~h}$ at room temperature, and washed twice in phosphate buffered saline (PBS) for $5 \mathrm{~min}$. Endogenous peroxidase activity was quenched by treating sections with $0.3 \%$ hydrogen peroxide in PBS containing $0.1 \%$ triton for $30 \mathrm{~min}$ at $4{ }^{\circ} \mathrm{C}$. After two 5min washes in PBS, sections were incubated in PBS containing BSA (2\%) and goat serum (5\%) for $1 \mathrm{~h}$ at room temperature and quickly washed in PBS with BSA (0. 1\%). Sections were incubated overnight at $4{ }^{\circ} \mathrm{C}$ in PBS with BSA $(0.5 \%)$ with primary rabbit antibodies against bovine FFAR4 (19 $\mu \mathrm{g} / \mathrm{mL}$; customized antibody; AgroBio) or with the pre-immunized serum (similar IgG concentration; Agro-Bio) from the same rabbit (negative control). After four 5-min washes in PBS with Tween 20 $(0.1 \%)$, sections were then incubated with secondary biotinylated horse anti-mouse and anti-rabbit IgG (1:700 
dilution) in PBS with BSA (0.5\%) for $1 \mathrm{~h}$ at room temperature. After four 5-min washes in PBS with Tween 20 (0.1\%), sections were incubated in a ready-touse avidine and biotinylated horseradish peroxidase solution (Vectastain ${ }^{\oplus}$ Elite $^{\oplus} \mathrm{ABC}$ kit, Vector Laboratories) for $30 \mathrm{~min}$ at room temperature, according to the manufacturer's instructions. After three 5-min washes in PBS with Tween $20(0.1 \%)$, immunostaining was developed by incubating sections in $50 \mathrm{mM}$ Tris- $\mathrm{HCl}$ ( $\mathrm{pH} 7.8$ ) con-

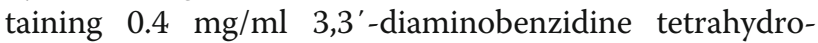
chloride dehydrate (DAB) and $0.007 \%$ hydrogen peroxide for $5 \mathrm{~min}$ at room temperature. Sections were then dehydrated and mounted using Depex. Immunospecific staining (brown) was observed using an Axioplan Zeiss transmission microscope coupled with a $10 \times$ objective with a numerical aperture of 0.03 or a $40 \times$ objective with a numerical aperture of 0.75 . Images were generated with a numerical camera piloted by the Software Spot (version 5.2 for Windows; Diagnostic Instruments, Inc., MicroMecanique, Evry, France).

\section{Immunofluorescence}

After collection and washes, as described above, GCs were incubated on a 8 -well chamber slide (Lab-Tek ${ }^{\odot}$ Nunc, Thermo-Fisher Scientific, Courtaboeuf, France) for $48 \mathrm{~h}$. Cells were then washed in Tris-buffer saline (TBS), fixed in PBS containing paraformaldehyde (4\%) for $20 \mathrm{~min}$ and washed in TBS-0.1\% BSA for $3 \mathrm{~min}$ at room temperature. After blocking in TBS containing BSA (1\%) and horse serum (5\%) for $1 \mathrm{~h}$ at room temperature, GCs were incubated overnight at $4{ }^{\circ} \mathrm{C}$ in TBS containing BSA (1\%) and horse serum (5\%) with primary rabbit antibodies against bovine FFAR4 (9. $5 \mu \mathrm{g} / \mathrm{mL}$; customized antibody) or the pre-immunized serum (similar IgG concentration) of the same rabbit (negative control). Other GCs were incubated in the same conditions with primary rabbit antibodies against human FFAR4 $(20 \mu \mathrm{g} / \mathrm{mL}$; Aviva Systems Biology) or rabbit IgG (similar concentration) as a negative control. After three 10-min washes in TBS containing BSA $(0.1 \%)$, sections were then incubated with secondary Alexa Fluor 488-conjugated donkey anti-rabbit IgG (1:800 dilution) in TBS containing BSA $(0.1 \%)$ for $1.5 \mathrm{~h}$ at room temperature. Then, GCs were washed in TBS containing BSA (0.1\%) (three 10-min washes), and incubated in TBS with $1 \mu \mathrm{g} / \mathrm{mL}$ Hoechst 33,258 for $15 \mathrm{~min}$ at room temperature to stain nuclei. Sections were then mounted using Moviol $^{\odot}$ and fluorescence was observed under a Zeiss confocal microscope LSM700 (Carl Zeiss Microscopy GmbH, Munich, Germany) using an oil $40 \times$ objective with a numerical aperture of 1.3 or an oil $63 \times$ objective with a numerical aperture of 1.4 and the appropriate filters. Images were captured using Zen 2012 software (black edition version 8.0, Carl Zeiss Microscopy GmbH).

\section{GC proliferation}

Cell proliferation was determined by measurement of ${ }^{3} \mathrm{H}$-thymidine incorporation into bovine GCs after $24 \mathrm{~h}$ of culture, as previously described [43] with some modifications. Briefly, GCs $\left(2.5 \times 10^{5}\right.$ viable cells $/ 250 \mu \mathrm{L}$ media/well) were cultured in 48-well dishes in modified McCoy's $5 \mathrm{~A}$ media containing ${ }^{3} \mathrm{H}$-thymidine $(0.25 \mathrm{nCi} /$ $\mu \mathrm{L}$ corresponding to $18.5 \mathrm{kBq} / \mathrm{mL}$; Perkin Elmer, Courtaboeuf, France) in the presence or absence of DHA $(1,10,20$ or $50 \mu \mathrm{M})$ or TUG-891 $(1,10$ or $50 \mu \mathrm{M})$. Cultures were maintained at $38{ }^{\circ} \mathrm{C}$ in air containing $5 \% \mathrm{CO}_{2}$. After culture for $24 \mathrm{~h}$, excess thymidine was removed by washing twice with PBS $(200 \mu \mathrm{L} /$ well $)$. Cells were then fixed with cold $50 \%$ trichloroacetic acid (100 $\mu \mathrm{L} /$ well) for $15 \mathrm{~min}$ and lysed using $0.5 \mathrm{M} \mathrm{NaOH}(250 \mu \mathrm{L} /$ well $)$ for $10 \mathrm{~min}$ at room temperature. Radioactivity was counted using Ultima Gold MV scintillation fluid (Perkin Elmer) and a $\beta$-photomultiplier C2900 (Perkin Elmer). The results are expressed as mean \pm SEM of 13 independent cultures (cells from one culture came from several follicles originating from several ovaries (around 10 follicles per ovary, and 15 ovaries per cultures) and each culture came from a specific batch of ovaries), with four replicates of each treatment. Data are expressed as disintegrations per minute (dpm).

\section{Progesterone assay}

GCs were cultured in 96-well dishes $\left(1 \times 10^{5}\right.$ viable cells/ $150 \mu \mathrm{L}$ media/well) in modified McCoy's 5A medium in the presence or absence of DHA $(1,10,20$ or $50 \mu \mathrm{M})$ or TUG-891 (1, 10 or $50 \mu \mathrm{M})$ for $48 \mathrm{~h}$. Supernatants and cells were separately stored at $-20{ }^{\circ} \mathrm{C}$ until progesterone analysis and protein assays (BCA protein quantification kit;Interchim, Montluçon, France), respectively. The concentration of progesterone was determined in the culture media using an ELISA protocol, as described previously [44]. For progesterone concentrations ranging from 0.25 to $32 \mathrm{ng} / \mathrm{mL}$, the intra-assay coefficient of variation $(\mathrm{CV})$ averaged $<10 \%$. Progesterone secreted in each well was normalized by the protein concentration of the same well. The results are expressed as the amount of progesterone $(\mathrm{ng} / \mathrm{mL})$ secreted per $48 \mathrm{~h}$ per protein amount $(\mu \mathrm{g} / \mathrm{mL})$ per well. Data, representing 12 independent cultures (as described in GC-proliferation section) with each treatment conducted in quadruplicate, are expressed as mean \pm SEM and as ng of secreted progesterone per $\mu \mathrm{g}$ of protein.

\section{Estradiol assay}

GCs were cultured in 96-well dishes $\left(1 \times 10^{5}\right.$ viable cells/ $150 \mu \mathrm{L}$ media/well) in modified McCoy's 5A medium in 
the presence or absence of DHA $(1,10,20$ or $50 \mu \mathrm{M})$ or TUG-891 $(1,10$ or $50 \mu \mathrm{M})$ for $48 \mathrm{~h}$. Supernatants and cell layer were separately stored at $20{ }^{\circ} \mathrm{C}$ until estradiol analysis and protein assays (BCA protein quantification kit), respectively. The concentration of estradiol in the culture media was determined using the DIAsource E2-EASIA Kit (DIAsource, Louvain-la-Neuve, Belgium), in accordance with the manufacturer's recommendations. Briefly, $50 \mu \mathrm{L}$ of spent medium was used for the assay and the competition between unlabeled estradiol (present in the culture media) and labeled estradiol (provided by the kit) lasted overnight at $4{ }^{\circ} \mathrm{C}$. For estradiol concentrations ranging from 1.56 to $50 \mathrm{pg} / \mathrm{mL}$, the interassay CVs averaged $15 \%$. Estradiol was normalized as described for progesterone. Data, represented six independent cultures with each treatment conducted in quadruplicate, are expressed as mean \pm SEM as pg of secreted estradiol per $\mu \mathrm{g}$ of protein.

\section{Fatty acid analysis}

GCs were cultured in 48-well dishes $(2.5 \times 105$ viable cells $/ 250 \mu \mathrm{L}$ media/well) in modified McCoy's 5A medium in the presence or absence of DHA (1, 10 or $50 \mu \mathrm{M})$ for $15 \mathrm{~h}$. Supernatants were removed. Cells with the same treatment (pool of 12 wells) were isolated in PBS $1 \mathrm{X}$ and stored at $-80{ }^{\circ} \mathrm{C}$ until lipid analysis. Lipids were extracted and analyzed as previously described [45]. Briefly, total lipids were extracted twice from granulosa cells with ethanol/chloroform $(1: 2, v / v)$. Before extraction, 1,2-diheptadecanoyl-sn-gycero-3-phosphocholine (GPC di-17:0) was added as internal standard. Lipids were transmethylated with toluene-methanol $(2: 3, \mathrm{v} / \mathrm{v})$ and boron trifluoride in methanol (14\%) at $100{ }^{\circ} \mathrm{C}$ for $90 \mathrm{~min}$ in screw-capped tubes. After addition of $1.5 \mathrm{~mL} \mathrm{~K} 2 \mathrm{CO} 3$ in $10 \%$ water, the resulting fatty acid methyl esters (FAME) were extracted by $2 \mathrm{~mL}$ of isooctane. The FAMEs were analyzed by gas chromatography with a HP6890 instrument equipped with a fused silica capillary BPX70 SGE column $(60 \times 0.25 \mathrm{~mm})$. The vector gas was hydrogen. Temperatures of the Ross injector and the flame ionization detector were set at $230{ }^{\circ} \mathrm{C}$ and $250{ }^{\circ} \mathrm{C}$, respectively. FAMEs were identified by making a comparison of their relative retention times with those of commercial standards. Fatty acid composition is expressed as the mole percentage of total fatty acids. The results are expressed as means $\pm \operatorname{SEM}(n=4$ per treatment).

\section{Protein extraction and western blot analysis}

In order to validate the FFAR4 antibody designed against the bovine protein, proteins were extracted from lung tissue. Moreover, on GC, assays were conducted for proliferating cell nuclear antigen (PCNA), for steroidogenic enzymes, cytochrome P450 family 11 subfamily A member 1 (CYP11A1 alias cholesterol side-chain cleavage) and hydroxy-delta-5-steroid dehydrogenase, 3 beta- and steroid delta-isomerase 1 (HSD3B1 alias 3 $\beta$-HSD), and for the cholesterol transporter steroidogenic acute regulatory protein (StAR). GCs were cultured in 48-well dishes $\left(2.5 \times 10^{5}\right.$ viable cells $/ 250 \mu \mathrm{L}$ media/well $)$ in modified McCoy's 5A medium in the presence or absence of DHA for $15 \mathrm{~h}$. Five independent experiments were performed for HSD3B1, StAR, CYP11A1 after DHA $20 \mu \mathrm{M}$ treatment and six independent experiments for PCNA after DHA $10 \mu \mathrm{M}$ treatment.

Cell signaling pathway assays were conducted for AMP-activated protein kinase $\alpha(\mathrm{AMPK} \alpha)$, MAPK14, MAPK1/3 and Akt as these pathways are of interest to explore GC functions. Indeed, these pathways are involved in both cellular proliferation and steroidogenesis, the functions investigated in the present study. GCs were cultured in 48 -well dishes $\left(2.5 \times 10^{5}\right.$ viable cells/ $250 \mu \mathrm{L}$ media/well) in modified McCoy's 5A medium. After $15 \mathrm{~h}, 100 \mu \mathrm{L}$ supernatant was removed and replaced with $100 \mu \mathrm{L}$ fresh modified McCoy's 5A medium in the presence or absence of DHA (10 or $50 \mu \mathrm{M}$ final concentration in well) or TUG-891 (1, 10 or $50 \mu \mathrm{M}$ final concentration in well) for $5,10,30$ or $60 \mathrm{~min}$. Four independent experiments were performed.

With all assays, analyses were performed on total protein extracts from cultured GCs or from lung tissue in the case or FFAR4 validation. Total proteins were extracted from GCs on ice in lysis buffer (10 mM Tris (pH 7.4), $150 \mathrm{mM} \mathrm{NaCl,} 1$ mM EDTA, 2 mM EGTA, 0.5\% Nonidet P40, 1\% Triton X 100) containing phosphatase inhibitors $(10 \mathrm{mM}$ sodium fluoride, $12 \mathrm{mM}$ sodium dihydrogen phosphate, $2 \mathrm{mM}$ sodium orthovanadate). In the case of lung tissue, proteins were extracted on ice after $2 \mathrm{~h}$ lysis buffer action in order to favor membrane receptor extraction. Lysates were centrifuged for $30 \mathrm{~min}$ at $4^{\circ}$ $\mathrm{C}$ at $16000 \mathrm{~g}$ for GC proteins and $6000 \mathrm{~g}$ (to favor membrane receptor recovery) for lung proteins. The protein concentration in the supernatants was determined using a colorimetric assay (kit BC Assay protein quantification; Interchim, Montluçon, France) and proteins were denaturated in Laemmli buffer for $5 \mathrm{~min}$ at $95{ }^{\circ} \mathrm{C}$. Protein lysates $(15 \mu \mathrm{g}$ GC or $150 \mu \mathrm{g}$ lung) were subjected to electrophoresis on $4-12 \%$ acrylamide gel (Life technologies, Saint-Aubin, France) and electrotransferred onto $0.45-\mu \mathrm{m}$ nitrocellulose membranes (Pall Corporation, VWR International, France). After blocking with 5\% non-fat dry milk powder (NFDMP) in TBS-0.1\% Tween-20 (TBST) for $90 \mathrm{~min}$ at room temperature, blots were incubated with appropriate primary antibodies (for final dilutions, see Table 1) in TBST with 5\% NFDMP at $4{ }^{\circ} \mathrm{C}$ overnight. The membranes were then washed in TBST and incubated with the appropriate HRP-conjugated 
Table 1 Primer sequences for real-time reverse transcription-polymerase chain reaction

\begin{tabular}{|c|c|c|c|c|c|c|}
\hline Abbrev. & Gene & Accession no. & Forward primer & Reverse primer & $\mathrm{bp}$ & $\begin{array}{l}\mathrm{E} \\
\%\end{array}$ \\
\hline FFAR4 & Free fatty acid receptor 4 & XM_865266 & GGGTTCCTITTCGATGTGAA & GCCGTGACTCTTTGGAGAAG & 166 & 94 \\
\hline GPX4 & Glutathione peroxidase 4 & NM_174770 & CGATACGCCGAGTGTGGTITAC & ACAGCCGTTCTTGTCAATGAGG & 261 & 96 \\
\hline GLUT1 & $\begin{array}{l}\text { Solute carrier family } 2 \text { (facilitated glucose } \\
\text { transporter), member } 1\end{array}$ & NM_174602 & CTGATCCTGGGTCGCTTCAT & ACGTACATGGGCACAAAACCA & 68 & 113 \\
\hline$N F k B$ & $\begin{array}{l}\text { Nuclear factor of kappa light polypeptide } \\
\text { gene enhancer in B-cells } 1\end{array}$ & NM_001076409.1 & GCACCACTTATGACGGGACT & CCATGTCCAGAGGAGTGGTT & 195 & 89 \\
\hline PPARA & $\begin{array}{l}\text { Peroxisome proliferator-activated receptor } \\
\text { alpha }\end{array}$ & NM_001034036.1 & CCTACGGGAATGGCTTCATA & GCACAATACCCTCCTGCATT & 219 & 97 \\
\hline PPARG & $\begin{array}{l}\text { Peroxisome proliferator-activated receptor } \\
\text { gamma }\end{array}$ & Y12419/Y12420 & CCCTGGCAAAGCATTTGTAT & ACTGACACCCCTGGAAGATG & 222 & 88 \\
\hline RPL19 & Ribosomal protein L19 & BC102223 & AATCGCCAATGCCAACTC & CCCTITCGCTTACCTATACC & 156 & 94 \\
\hline RPS9 & Ribosomal protein $\mathrm{S9}$ & BC148016 & GGAGACCCTTCGAGAAGTCC & GGGCATTACCTTCGAACAGA & 180 & 100 \\
\hline SREBF1 & $\begin{array}{l}\text { Sterol regulatory element binding } \\
\text { transcription factor } 1\end{array}$ & AB355703.1 & ACCGCTCTTCCATCAATGAC & TTCAGCGATTTGCTTTTGTG & 190 & 97 \\
\hline
\end{tabular}

Abbrev gene abbreviation, $b p$ product size in base pair, $E$ primer efficiency

secondary antibody (final dilution 1:5000) in TBST with 5\% NFDMP for $2 \mathrm{~h}$ at room temperature. The signal of specific bands, detected by ECL (West Dura; Thermo-Fisher Scientific, Courtaboeuf, France), was quantified using a chargecoupled device camera GeneGnome (Syngene, Cambridge, United Kingdom) with Genesys 1.5.4 software (Syngene). The analysis of signal intensity was performed using GeneTools 4.01 software (Syngene). Results for PCNA, HSD3B1, StAR and CYP11A1 expression levels are expressed as the fold change between controls and DHA treatment. Results of MAPK14, AMPKa, Akt and MAPK1/3 phosphorylation are expressed as the ratio of phosphorylated protein to total protein, normalized by the control value at the same time-point, and with time 0 min being equal to 1 (for reference).

\section{Gene expression analysis in GCs}

GCs were cultured in 48-well dishes $\left(2.5 \times 10^{5}\right.$ viable cells $/ 250 \mu \mathrm{L}$ media/well) in modified McCoy's 5A medium in the presence or absence of DHA $(1,10,20$ or $50 \mu \mathrm{M})$ or TUG-891 $(1,10$ or $50 \mu \mathrm{M})$ for $8 \mathrm{~h}$. After removal of the medium, cells were recovered using $200 \mu \mathrm{l} /$ well of TriZol reagent (Invitrogen, Cergy Pontoise, France), immediately frozen and stored until analysis. An additional condition, consisting in GC collected from ovaries and then immediately frozen and stored until analysis was also constituted and named in vivo GC. Total RNA was extracted from GCs according to the manufacturer's instructions. RNA concentration was determined using a NanoDrop ND-1000 spectrophotometer (Nyxor Biotech, Paris, France). DNAse treatment and reverse transcription (RT) was performed on $1 \mu \mathrm{g}$ of total RNA extracted from GCs using Maxima First Strand cDNA Synthesis kit (Thermo-Fisher Scientific) according to the manufacturer's recommendations.
Real-time PCR reactions were carried out on a CFX96 (Bio-Rad, Marnes-la-Coquette, France) in $20 \mu \mathrm{L}$ volumes containing primers, each at a final concentration of $150 \mathrm{nM}$ (Table 1), $5 \mu \mathrm{L}$ of the diluted RT reaction (10 ng cDNA per reaction) and qPCR Mastermix Plus for Sybr Green I (Bio-Rad) according to the manufacturer's instructions. As expression of FFAR4 and FFAR1 in ovarian tissue is low, real-time RT-PCR were performed on $50 \mathrm{ng}$ cDNA per reaction. The efficiency of the primers (Table 2) and standard curve for each gene were calculated from serial dilutions of the corresponding cDNA fragment obtained as a template. Relative gene expression levels were determined in ten independent GC samples for each treatment. The geometric mean of two housekeeping genes, Ribosomal protein L19 (RPL19) and Ribosomal protein S9 (RPS9), was used to normalize gene expression. The relative amounts of gene transcripts $(R)$ were calculated according to the equation: $R$ $=\frac{\left(E_{\text {gene }}^{-C \text { gene }}\right)}{\left(\text { geometric mean }\left(E_{R P S 9}^{-C t R P S} ; E_{R P L 19}^{-C t R P L 19}\right)\right)}$, where $\mathrm{E}$ is the primer efficiency and $\mathrm{Ct}$ the cycle threshold.

\section{Statistical analysis}

Statistical analyses were performed for GC proliferation, steroidogenesis, gene expression, protein expression, GC lipid composition taking into account treatment effect and replica effect. Concerning cell signaling, the time effect and replica effect were analyzed. GC proliferation, progesterone secretion, estradiol secretion, GC lipid composition and cell signaling were compared between the groups. A one-way ANOVA was used when distribution and variance enabled performance of a parametric study (Shapiro test, Levene test, Rcmdr package), with Tukey's post hoc comparison ( $\mathrm{R}$ package multcomp 
Table 2 Fatty acid composition from total lipids of bovine granulosa cells after $15 \mathrm{~h}$ treatment with DHA

\begin{tabular}{|c|c|c|c|c|}
\hline $\begin{array}{l}\text { Fatty acids (mole } \\
\% \text { of total fatty } \\
\text { acids) }\end{array}$ & $\begin{array}{l}\text { Control }^{a} \\
n=5\end{array}$ & $\begin{array}{l}\text { DHA1 } \mu \mathrm{M} \\
n=4\end{array}$ & $\begin{array}{l}\text { DHA } 10 \mu \mathrm{M} \\
n=4\end{array}$ & $\begin{array}{l}\text { DHA } 50 \mu \mathrm{M} \\
n=3\end{array}$ \\
\hline \multicolumn{5}{|l|}{ Saturates } \\
\hline $16: 0$ & $31.50 \pm 7.48$ & $40.16 \pm 9.38$ & $44.12 \pm 11.60$ & $48.45 \pm 7.44$ \\
\hline $18: 0$ & $10.68 \pm 2.25$ & $13.36 \pm 3.03$ & $15.04 \pm 3.89$ & $16.24 \pm 2.60$ \\
\hline \multicolumn{5}{|l|}{ Monounsaturates } \\
\hline $16: 1 \mathrm{n}-7$ & $2.32 \pm 0.55$ & $3.03 \pm 0.72$ & $3.33 \pm 0.91$ & $3.52 \pm 0.68$ \\
\hline $18: 1 n-7$ & $8.93 \pm 2.17$ & $11.51 \pm 2.85$ & $12.36 \pm 3.72$ & $12.22 \pm 3.01$ \\
\hline $18: 1 \mathrm{n}-9 \mathrm{cis}$ & $29.99 \pm 7.18$ & $38.91 \pm 9.08$ & $42.49 \pm 11.58$ & $43.03 \pm 7.86$ \\
\hline \multicolumn{5}{|l|}{ n-6 PUFA } \\
\hline $18: 2 \mathrm{n}-6$ cis & $6.05 \pm 1.29$ & $7.87 \pm 1.81$ & $8.59 \pm 2.33$ & $8.41 \pm 2.07$ \\
\hline $20: 4 n-6$ & $8.85 \pm 2.12$ & $11.87 \pm 3.08$ & $13.02 \pm 3.99$ & $11.24 \pm 4.10$ \\
\hline \multicolumn{5}{|l|}{ n-3 PUFA } \\
\hline $18: 3 n-3$ & $0.51 \pm 0.12$ & $0.66 \pm 0.15$ & $0.74 \pm 0.18$ & $0.67 \pm 0.17$ \\
\hline $20: 5 n-3$ & $0.98 \pm 0.25$ & $1.34 \pm 0.31$ & $1.60 \pm 0.38$ & $1.37 \pm 0.42$ \\
\hline $22: 5 n-3$ & $7.03 \pm 1.72$ & $9.33 \pm 2.28$ & $10.04 \pm 2.90$ & $7.79 \pm 3.31$ \\
\hline $22: 6 n-3(\mathrm{DHA})$ & $0.84 \pm 0.16$ & $2.17 \pm 0.04 *$ & $10.27 \pm 0.11 *$ & $23.05 \pm 6.58 *$ \\
\hline
\end{tabular}

Granulosa cells (GC) $\left(2.5 \times 10^{5}\right.$ viable cells $/ 250 \mu \mathrm{L}$ media/well) were cultured into 48 -well dishes in modified McCoy's $5 \mathrm{~A}$ media in the presence or absence of DHA $(1,10$ or $50 \mu \mathrm{M})$. After $15 \mathrm{~h}$ culture, supernatants were removed and cells with the same treatment (12 wells) were pooled and stored under nitrogen gas at $-80^{\circ}$ $\mathrm{C}$ until the total lipid extraction. The fatty acid analysis was performed by gas chromatography by the Plateforme de Lipidomique Fonctionnelle (INSA, Villeurbanne, France). The relative amount of each fatty acid is expressed as the area of each fatty acid peak, relative to the total area for all fatty acids (mole\%). The results are expressed as means \pm SEM ( $n=4$ per treatment). ${ }^{\text {a }}$ Control corresponds to the serum-free modified McCoy's 5 A medium supplemented with DMSO $(1: 2000)$ as carrier solvent of DHA. The prepared mediums with the different concentrations of DHA were all adjusted for DMSO at 1:2000. ${ }^{*}$ indicates a significant difference with control condition (Kruskal-Wallis test with Tukey's multiple comparison test as post-hoc test, $p<0.05$ )

[46]). A non-parametric ANOVA (permutational ANOVA) was used when distribution was not normal and variance was not homogenous ( $R$ package lmPerm [47]), with a Tukey's post-hoc test ( $R$ package nparcomp [48]), $\mathrm{R}$ version 3.3.1 [49]). Gene expression was analyzed using K-sample Fisher Pitman permutation test with a Monte Carlo approximation (Rcmdr package) with the treatment as a fixed factor and the replica as a random factor, with Tukey's post hoc comparison ( $\mathrm{R}$ package nparcomp). Protein expression levels of PCNA, HSD3B1, StAR and CYP11A1 were analyzed using the Kruskal-Wallis test (Shapiro test, Levene test, Rcmdr package). A $p$-value of $\leq 0.05$ was considered to indicate a significant difference and $0.05<p \leq 0.10$ a tendency.

\section{Results}

\section{FFAR4 expression}

Both FFAR1 and FFAR4 mRNA were detectable at a low level in several ovarian compartments, such as the cortex and theca, granulosa and cumulus cells (Additional file 4: Figure S3). An antibody was designed against a peptide from the second extracellular loop of the FFAR4 bovine protein. The signal corresponding to the $42 \mathrm{kDa}$ band was extinguished by increasing the quantity of peptide used to prepare the antibody, demonstrating that the band corresponded to FFAR4 (Additional file 1: Figure S1). The protein FFAR4 was detected by both immunohistochemistry (brown labelling, Fig. 1) on bovine ovarian follicles and immunofluorescence (green fluorescence, Fig. 2) on cultured bovine GCs, using the bovine FFAR4 antibody. FFAR4 protein was present in all cellular types of follicles with small and large antrum. FFAR4 protein immunofluorescence seemed to exhibit a peripheral labelling close to the cellular membrane in some GCs and the intensity and presence of the staining was variable in GCs cultured in vitro (Fig. 2). The precise localization of the labelling to the cellular membrane is not obvious in all cells. This signal is similar to FFAR4 immunofluorescence in bovine GCs, obtained using a commercial antibody design against a peptide of the human protein sharing $89 \%$ identity with the bovine FFAR4 sequence (Additional file 5: Figure S4).

\section{Cellular proliferation}

DHA significantly increased basal cellular proliferation at $10 \mu \mathrm{M}$ (1.9-fold increase; $p<0.0001)$ and $50 \mu \mathrm{M}$ (1.8-fold increase; $p<0.0001$ ) compared to the control (Fig. 3). A similar increase in GC proliferation was also observed with TUG-891 at $1 \mu \mathrm{M}$ (1.7-fold increase; $p=0.014)$ and $50 \mu \mathrm{M}$ (2.2-fold increase; $p<0.0001$; Fig. 3).

\section{Steroidogenesis}

DHA significantly increased basal progesterone secretion at $20 \mu \mathrm{M}(1.3$-fold increase; $p<0.0001)$ and $50 \mu \mathrm{M}(1.2-$ 


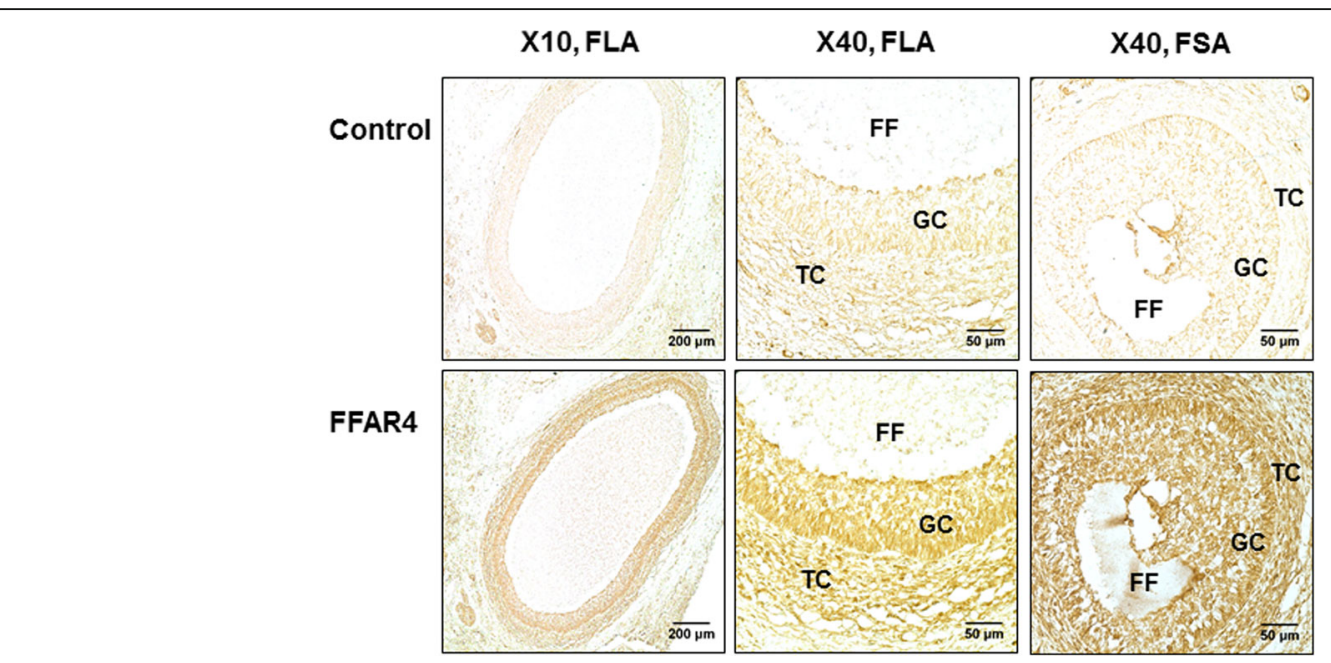

Fig. 1 Expression of free fatty acid receptor 4 (FFAR4) in bovine ovarian follicles by immunohistochemistry. Immunohistochemistry was performed on sections of ovarian follicles. FFAR4 (brown labeling) was immunodetected in ovarian follicles with large (FLA) or small (FSA) antrum (customized FFAR4 rabbit antibody, Agro-Bio). Pre-immunized rabbit serum was used as the control with the same secondary antibody as for FFAR4 detection. Bars $=200 \mu \mathrm{m}$ and $50 \mu \mathrm{m}$ for 10x and 40x microscope objectives, respectively. FF - follicular fluid, GC - granulosa cells, TC - theca cells

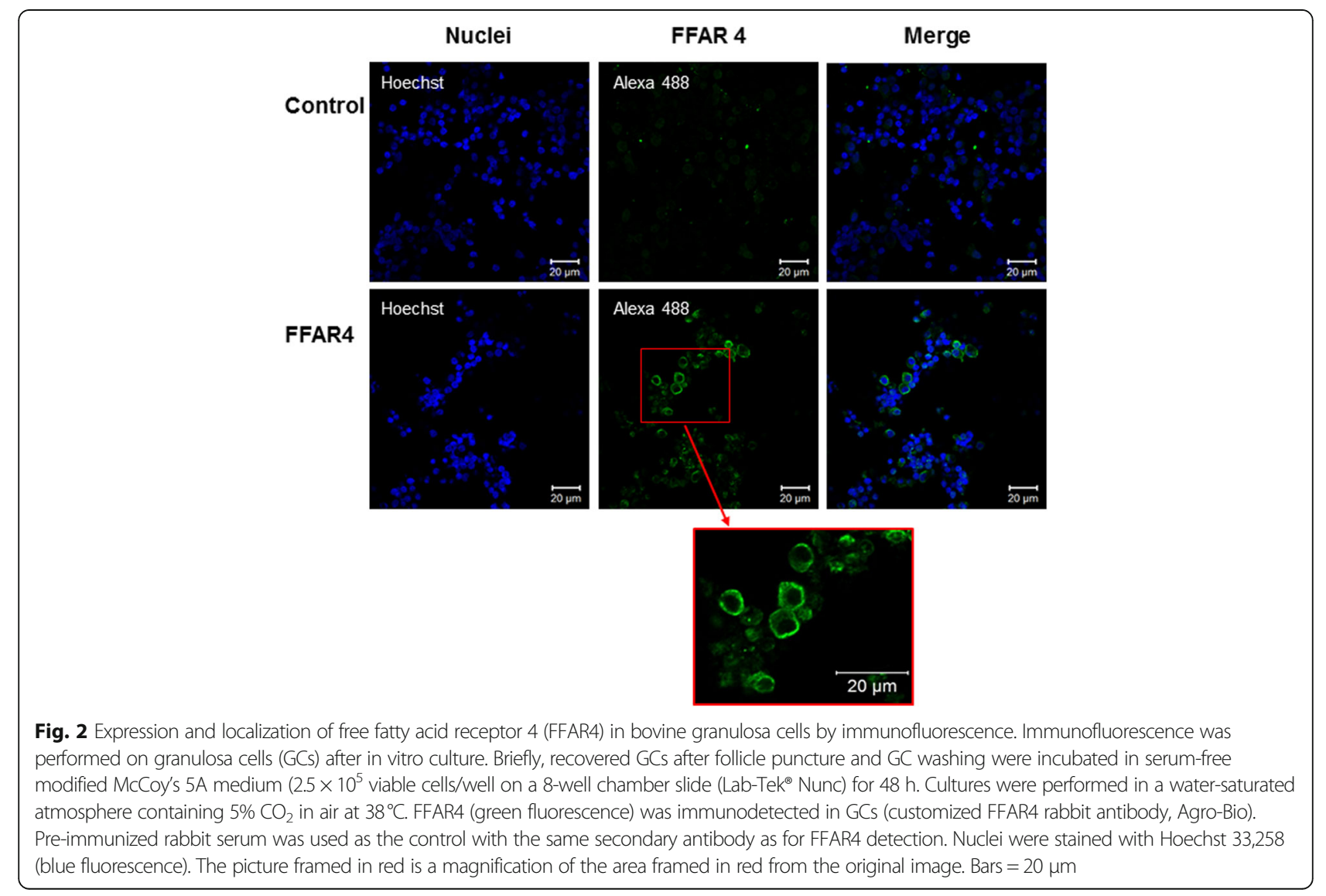




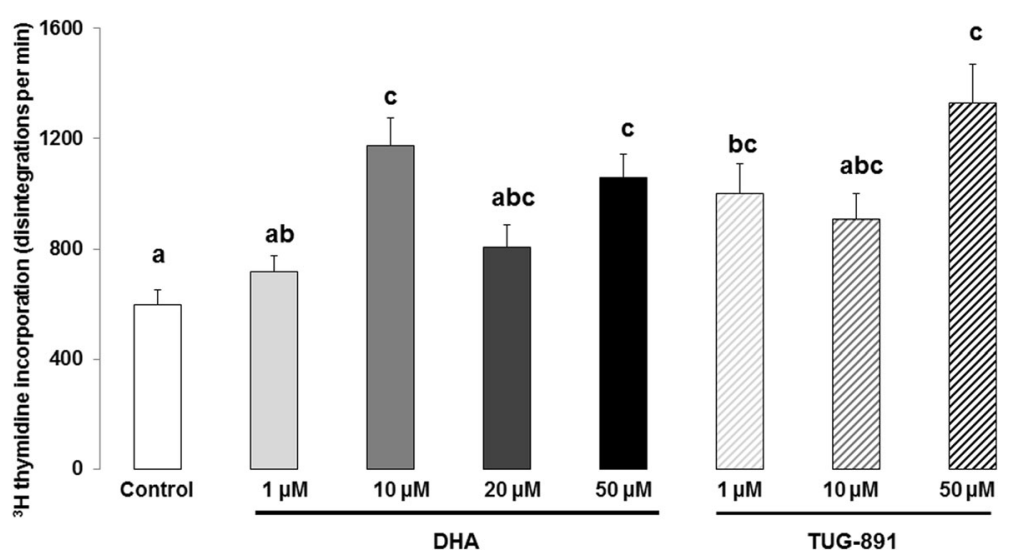

Fig. 3 Synthesis of DNA in bovine granulosa cells: ${ }^{3} \mathrm{H}$-thymidine incorporation after $24 \mathrm{~h}$ treatment with DHA or TUG-891. Effects of DHA or TUG-891 on cell proliferation were assessed by measurement of ${ }^{3} \mathrm{H}$-thymidine incorporation in bovine granulosa cells after $24 \mathrm{~h}$ culture in enriched McCoy's 5A media with various doses of DHA (1, 10, 20 and $50 \mu \mathrm{M})$ or TUG-891 (1, 10 and $50 \mu \mathrm{M})$, as described in Material and Method section. The chemical DMSO alone (1/2000) was used as a negative control due to its use as a solvent for DHA and TUG-891. The data are expressed as disintegrations per minute. Results represent 13 independent cultures with each treatment conducted in four replicates and are presented as mean \pm SEM. Bars with different superscripts are significantly different $(p<0.05)$

fold increase; $p=0.028$ ) compared to the control (Fig. 4). With regard to the effect of TUG-891, no significant effect was observed on progesterone secretion at any concentration (Fig. 4).

DHA significantly increased basal estradiol secretion at $10 \mu \mathrm{M}(1.2$-fold increase; $p=0.030)$ and $20 \mu \mathrm{M}(1.3$-fold increase; $p<0.0001$ ) compared to the control (Fig. 5). No effect of TUG-891 on estradiol secretion was reported at any concentration (Fig. 5).

\section{Protein expression}

PCNA expression level was analyzed by western blotting in GCs after $15 \mathrm{~h}$ in the presence or absence of DHA
(10 $\mu \mathrm{M}$; Fig. 6a Additional file 6: Figure S6), as this dose exhibited the highest significant effect on GC proliferation. DHA showed a tendency to increase PCNA expression levels (1.9-fold increase; $p=0.055$ ). Expression levels of the steroidogenic enzymes, HSD3B1 and CYP11A1, and the cholesterol transporter StAR, were analyzed by western blotting in GCs after $15 \mathrm{~h}$ in the presence or absence of DHA $(20 \mu \mathrm{M}$; Fig. 6b-d, respectively, Additional file 6: Figure S6), as this dose exhibited the highest significant effect on GC progesterone and estradiol secretion. DHA showed a significant 1.88 -fold increase in HSD3B1 expression ( $p=0.028)$, a significant 1. 67-fold increase in StAR expression $(p=0.016)$ and a

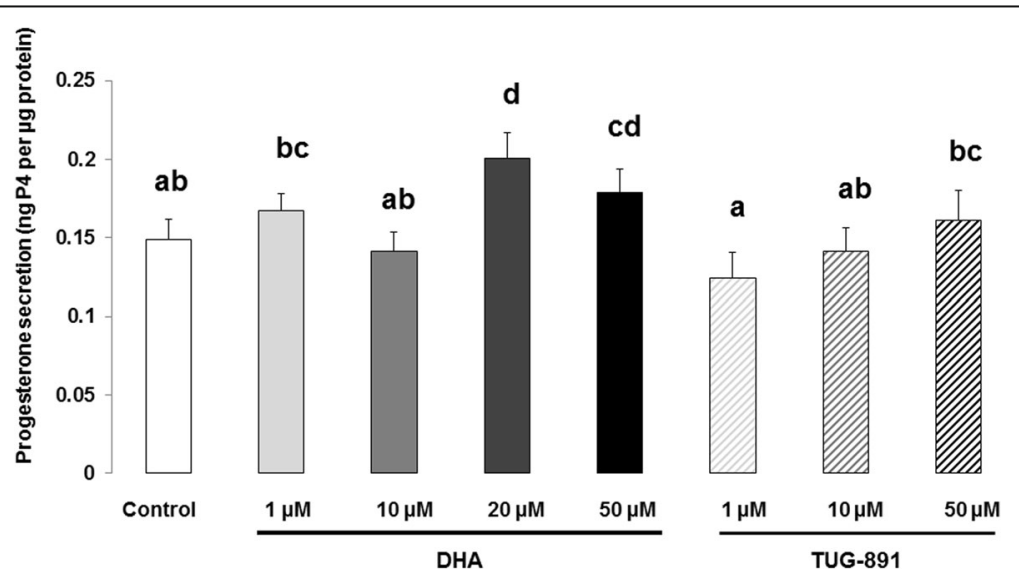

Fig. 4 Progesterone secretion from bovine granulosa cells after $48 \mathrm{~h}$ treatment with DHA or TUG-891. Effects of DHA or TUG-891 on progesterone secretion were assessed in culture media of bovine granulosa cells cultured for $48 \mathrm{~h}$ in enriched McCoy's 5A media with various doses of DHA (1, 10, 20 and $50 \mu \mathrm{M})$ or TUG-891 (1, 10 and $50 \mu \mathrm{M})$, as described in Material and Method section. The chemical DMSO alone (1/2000) was used as a negative control due to its use as a solvent for DHA and TUG-891. Progesterone secretion was normalized with the protein concentration in each well and expressed as ng progesterone (P4) per $\mu \mathrm{g}$ protein. Results of 12 independent cultures, with each treatment conducted in quadruplicate, are presented as mean \pm SEM. Bars with different superscripts are significantly different $(p<0.05)$ 


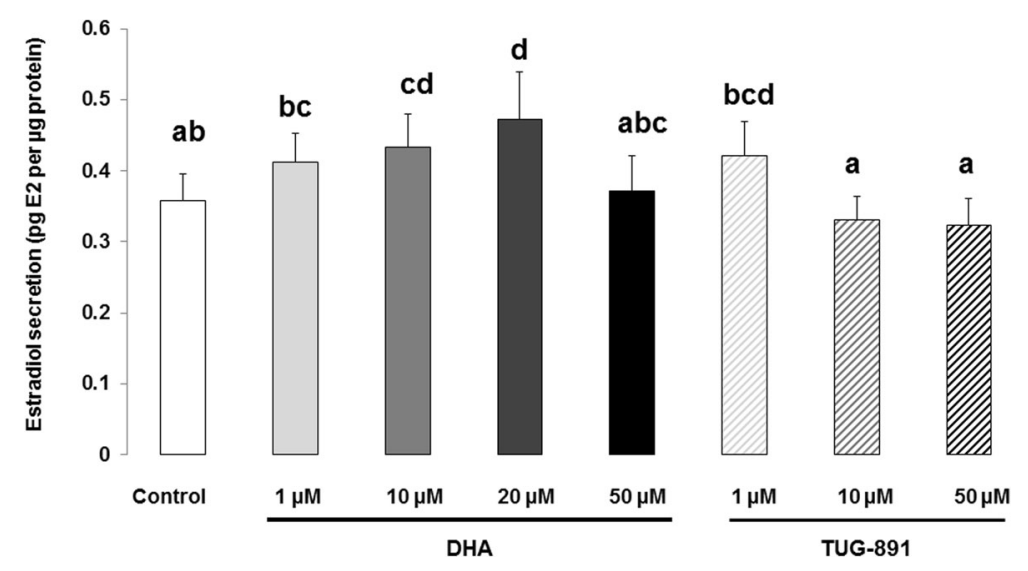

Fig. 5 Estradiol secretion from bovine granulosa cells after $48 \mathrm{~h}$ treatment with DHA or TUG-891. Effects of DHA or TUG-891 on estradiol secretion were assessed in culture media of bovine granulosa cells cultured for $48 \mathrm{~h}$ in enriched McCoy's 5A media with various doses of DHA (1, 10, 20 and $50 \mu \mathrm{M})$ or TUG-891 (1, 10 and $50 \mu \mathrm{M})$, as described in Material and Method section. The chemical DMSO alone (1/2000) was used as a negative control due to its use as a solvent for DHA and TUG-891. Estradiol secretion was normalized with the protein concentration in each well and expressed as pg estradiol (E2) per $\mu \mathrm{g}$ protein. Results of six independent cultures, with each treatment conducted in quadruplicate, are presented as mean \pm SEM. Bars with different superscripts are significantly different $(p<0.05)$

significant 2-fold increase in CYP11A1 expression $(p=0.047)$.

\section{Gene expression}

Gene expression of several candidate genes previously reported to be involved in n-3 PUFA effects: GLUT1 (involved in glucose metabolism), GPX4 (involved in oxidative stress), PPARA, PPARG and SREBF1, 3 transcription factors (involved in lipid metabolism) and FFAR4 (membrane receptor able to bind DHA and $N F \kappa B$, a signaling molecule reported to be involved in DHA action) (Fig. 7). Four genes showed a significant condition effect: GPX4 $(p=0.026)$, $N F K B(p=0.003)$, PPARA $(p=0.050)$ and SREBF1 $(p=0$. 015). GPX4, PPARA and NFKB exhibited a significant 2.6-

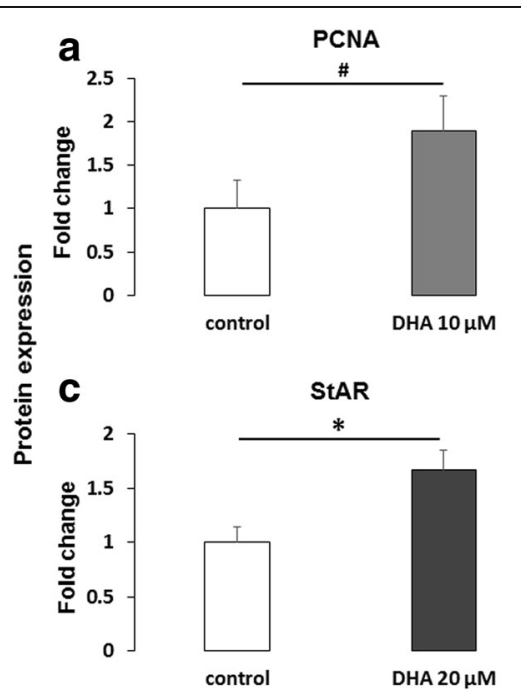

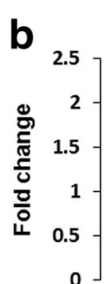

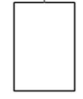

control

d
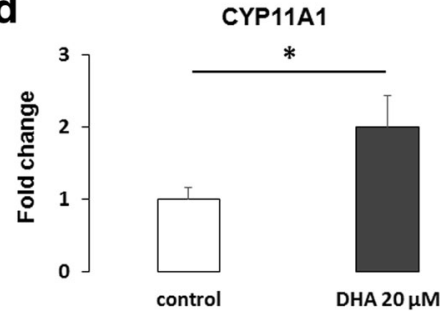

Fig. 6 Protein expression of (a) proliferating cell nuclear antigen (PCNA), (b) hydroxy-delta-5-steroid dehydrogenase, 3 beta- and steroid delta-isomerase 1 (HSD3B1), (c) steroidogenic acute regulatory protein (StAR) and (d) cytochrome P450 family 11 subfamily A member 1 (CYP11A1) after $15 \mathrm{~h}$ treatment with DHA. Effects of DHA treatment on protein levels were assessed in bovine granulosa cells after $15 \mathrm{~h}$ culture in enriched McCoy's 5A media in presence or absence of DHA 10 or $20 \mu \mathrm{M}$. The chemical DMSO alone (1/2000) was used as a negative control due to its solvent activity on DHA. Protein extracts were separated by electrophoresis on 4-12\% (w:v) SDS-polyacrylamide gel. After electrotransfer to nitrocellulose membranes, the proteins were probed with anti-PCNA (a), anti-HSD3B1 (b), anti-StAR (c) or anti-CYP11A1 (d) antibodies. The blots were stripped and re-probed with antibodies against Vinculin (VCL). Results of at least five independent experiments are presented. Bands on the blots were quantified and the total protein / VCL protein ratio was calculated. Results are expressed relative to the control as mean \pm SEM of five independent experiments for HSD3B1, StAR, CYP11A1 and six independent experiments for PCNA. * indicates significant difference $(p<0.05)$ and \# indicates tendency $(p<0.10)$ 
fold increase $(p=0.004), 5.4$-fold increase $(p=0.004)$, and 4.5 -fold increase $(p=0.018)$, respectively, in expression with TUG-891 $(10 \mu \mathrm{M})$ compared to the control. NFKB also exhibited a significant 4.3-fold increase in expression with DHA $50 \mu \mathrm{M}$ compared to the control $(p=0.028)$. No other treatments caused any difference in gene expression compared to controls.

\section{Cell signaling pathways}

MAPK14, AMPK $\alpha$, Akt and MAPK1/3 pathways were investigated after $5,10,30$ or $60 \mathrm{~min}$ in the presence or absence of DHA (10 or $50 \mu \mathrm{M})$ or TUG-891 $(1,10$ or $50 \mu \mathrm{M}$, Fig. 8, Additional file 7: Figure S5 and Additional file 8: Figure S7). The non parametric ANOVA showed a significant treatment effect for Akt $(p=0.005)$, AMPK $\alpha$ $(p=0.001)$, MAPK1/3 $(p=0.048)$ and MAPK14 $(p<0$. 001). Only for MAPK14 phosphorylation, a significant time effect was reported $(p<0.001)$, and significant time by treatment interaction were reported for MAPK14 $(p<0.0001), \mathrm{MAPK} 1 / 3 \quad(p=0.040)$ and AMPK $\alpha(p=0$. 008). The significant time by treatment interaction meant that the cells did not respond similarly across time to all doses of DHA and TUG-891. We therefore analyzed the effect of time for each treatment used.

The main changes were observed on MAPK14 pathway (Fig. 8a and Additional file 7: Figure S5A). Treatment with DHA $(10 \mu \mathrm{M})$ led to a significant 8.7 -fold increase in MAPK14 phosphorylation at $30 \mathrm{~min}$ compared to the control $(p=0.007$; Fig. 8a). Treatment with DHA $(50 \mu \mathrm{M})$ led to significant 5.4-fold and 8.4-fold increases in MAPK14 phosphorylation at $5 \min (p=0.035)$ and $30 \mathrm{~min}(p=0.001)$, respectively; a similar tendency was observed at $10 \mathrm{~min}$ (5.0-fold increase; $p=0.054$, Additional file 5: Figure S4A). Treatment with TUG-891 $(1 \mu \mathrm{M}$ and $50 \mu \mathrm{M})$ led to significant 7.5fold and 22.5-fold increases in MAPK14 phosphorylation at $30 \mathrm{~min}$, respectively, compared to the control $(p=0.026$ and 0.024 , respectively; Fig. 8a; Additional file 5: Figure S4A). Treatment with TUG-891 $(10 \mu \mathrm{M})$ led to a significant 7.6-fold increase in MAPK14 phosphorylation at $10 \mathrm{~min}$ compared to the control $(p=0.031)$; a similar tendency was observed at $5 \mathrm{~min}$ (6.0-fold increase; $p=0.091$; Additional file 5: Figure S4A). Whilst no effect was observed on Akt and AMPK $\alpha$ phosphorylation after DHA treatment at $10 \mu \mathrm{M} \quad$ (Fig. 8c) or $50 \mu \mathrm{M}$ (data not shown), treatment with TUG-891 $(1 \mu \mathrm{M})$ resulted in a significant 5.3-fold increase in Akt phosphorylation at $5 \mathrm{~min}(p$ $=0.020$; Fig. $8 \mathrm{c}$ ) and a 13.2-fold increase in AMPK $\alpha$ phosphorylation at $5 \mathrm{~min}(p=0.029$; Fig. $8 \mathrm{~b})$ compared to the control. Moreover, treatment with TUG$891(50 \mu \mathrm{M})$ led to a significant 5.8 -fold increase in AMPK $\alpha$ phosphorylation at $30 \min (p=0.039)$; a similar tendency was observed at $60 \mathrm{~min}$ (5.5-fold increase; $p=0.053$; Additional file 7: Figure S5B). Finally, no effect was observed on MAPK1/3

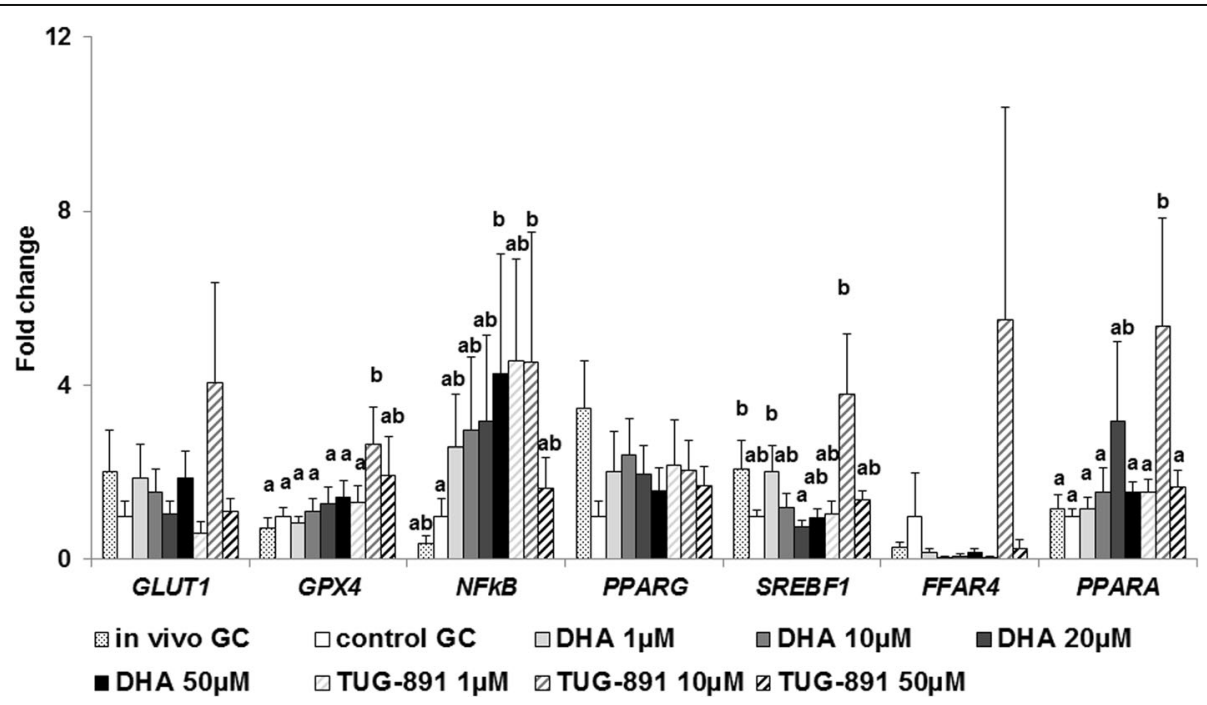

Fig. 7 Gene expression in bovine granulosa cells before or after $8 \mathrm{~h}$ treatment with DHA or TUG-891. Effects of DHA or TUG-891 on mRNA expression of solute carrier family 2 member 1 (GLUT1), glutathione peroxidase 4 (GPX4), nuclear factor of kappa light polypeptide gene enhancer in B-cells 1 (NFkB), peroxisome proliferator-activated receptor gamma (PPARG), sterol regulatory element binding transcription factor 1 (SREBF1), free fatty acid receptor 4 (FFAR4) and PPAR alpha (PPARA) were assessed in bovine granulosa cells (GC) before or after $8 \mathrm{~h}$ culture in enriched McCoy's $5 \mathrm{~A}$ media with various doses of DHA (1, 10, 20 and $50 \mu \mathrm{M})$ or TUG-891 (1, 10 and $50 \mu \mathrm{M})$, as described in Material and Method section. The chemical DMSO alone (1/2000) was used as a negative control due to its use as a solvent for DHA and TUG-891. Total mRNA was extracted from GC and reverse-transcribed, and real-time RT-PCR was performed. The geometric mean of two housekeeping genes (RPL19- ribosomal protein L19 and RPS9- ribosomal protein S9) was used to normalize gene expression. Results of 10 independent cultures are presented as mean \pm SEM. Bars with different superscripts are significantly different $(p<0.05)$ 

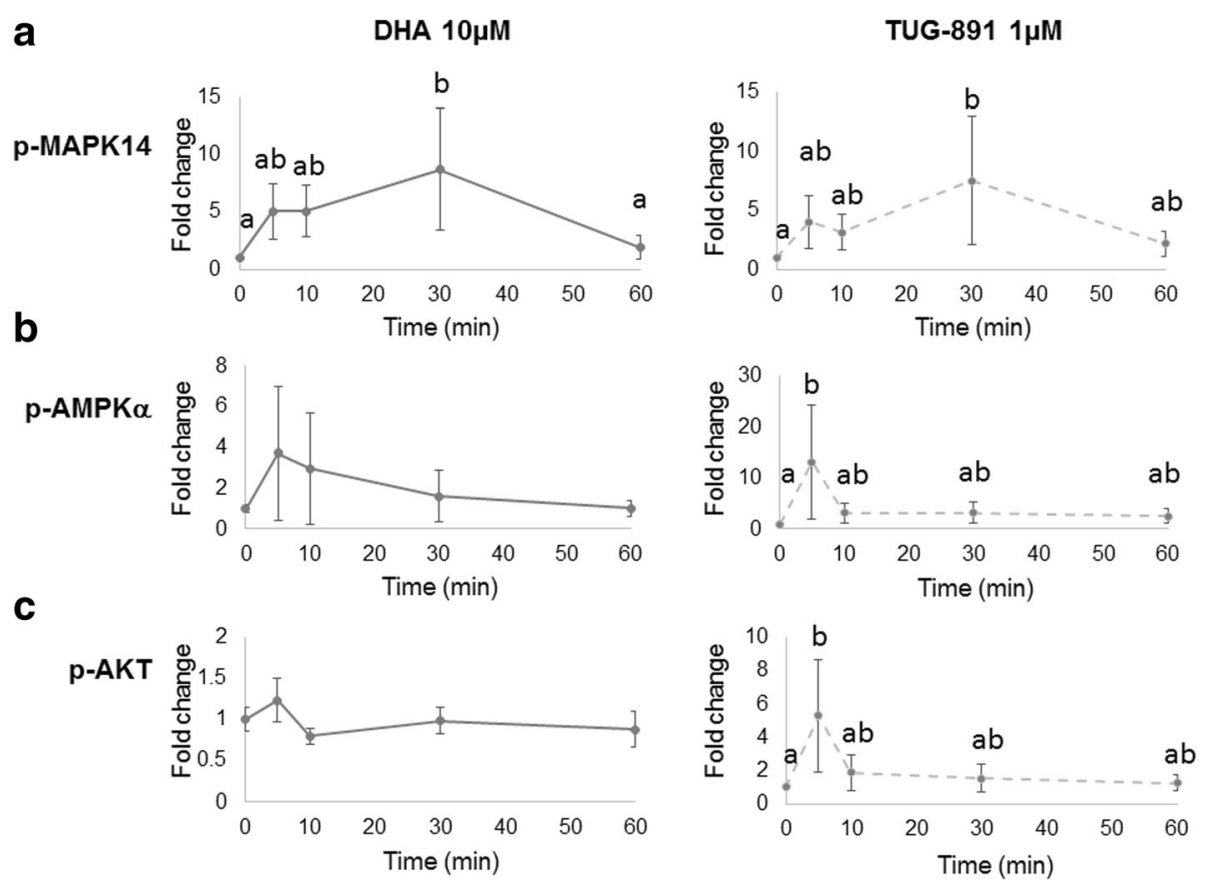

Fig. 8 Signaling pathways in bovine granulosa cells after DHA or TUG-891 treatment. Effects of DHA or TUG-891 on phosphorylation of (a) mitogen-activated protein kinase 14 (MAPK14), (b) AMP-activated protein kinasea (AMPKa) and (c) protein kinase B (Akt) signaling pathways were assessed in bovine granulosa cells cultured for $15 \mathrm{~h}$ in enriched McCoy's 5A media with 10 MM DHA or $1 \boldsymbol{\mu M}$ TUG-891, as described in Material and Method section for 5, 10, 30 and 60 min. Protein extracts were separated by electrophoresis on 4-12\% (w:v) SDS-polyacrylamide gel. After electrotransfer to nitrocellulose membranes, the proteins were probed with anti-phosphorylated (p-)MAPK14 (a), anti-p-AMPKa (b) or anti-p-AKT1/ 2/3 (c) antibodies. The blots were stripped and re-probed with antibodies against MAPK14, AMPKa or Akt, respectively. Bands on the blots were quantified. Results of four independent experiments are presented as the ratio of p-protein to total protein, normalized by the ratio observed in control at each time and expressed as mean \pm SEM of four independent experiments, with time 0 min being equal to 1 (for reference). Bars with different superscripts are significantly different $(p<0.05)$

phosphorylation with DHA $(10$ or $50 \mu \mathrm{M})$ or TUG$891(1$ or $10 \mu \mathrm{M})$ (data not shown). Only a transient, albeit significant, increase in MAPK1/3 phosphorylation was observed after 5 min treatment with TUG891 at $50 \mu \mathrm{M}$ (1.6-fold increase; $p=0.021$; Additional file 7: Figure S5C).

\section{DHA incorporation in granulosa cells}

Fatty acid composition was analysed in GC after DHA treatment on total fatty acids (Table 2). DHA $1 \mu \mathrm{M}$ led to a significant 2.6 -increase $(p<0.032) 10 \mu \mathrm{M}$ led to a significant 12 -fold increase $(p<0.0055)$ and DHA $50 \mu \mathrm{M}$ led to a significant 27 -fold increase $(p<0.0016)$ in DHA lipid composition. No other difference in FA lipid composition was reported between groups.

\section{Discussion}

In the present study, we investigated the effect of DHA treatment on bovine GCs in culture. For the first time, we showed that the addition of $10 \mu \mathrm{M}$ and $50 \mu \mathrm{M}$ DHA increased cellular proliferation, that the addition of $20 \mu \mathrm{M}$ and $50 \mu \mathrm{M}$ DHA increased progesterone secretion and that the addition of $10 \mu \mathrm{M}$ and $20 \mu \mathrm{M}$ DHA increased estradiol secretion. We also performed experiments to decipher the possible mechanisms of DHA action on GC functions. We showed that DHA increased PCNA, StAR and steroidogenic enzyme HSD3B1 and CYP11A1 protein expression and MAPK14 phosphorylation. We also reported, for the first time, the mRNA and protein expression of FFAR4 in bovine GCs and showed that FFAR4 activation by the FFAR4 agonist TUG-891 led to a similar increase in cellular proliferation and MAPK14 phosphorylation as with DHA treatment. However, TUG-891 treatment did not lead to increases in steroid secretion.

\section{DHA increased in vitro granulosa cell proliferation}

We reported here that DHA (10 and $50 \mu \mathrm{M})$ increased cellular proliferation of GCs in vitro. This finding is relevant to the increase in PCNA expression that we also observed after DHA treatment. Indeed, PCNA is involved in both DNA synthesis and repair [50]. Such effects of n-3 PUFAs on GC proliferation have already been reported in ovine cells in vitro [51]. Moreover, our in vitro results are also consistent with in vivo $n-3$ PUFA dietary supplementation data previously reported for 
bovine animals. Indeed, n-3 PUFA-enriched diets have resulted in increases in the pre-ovulatory follicle size [9, 10], and the number of total follicles [16], small follicles [17], medium follicles [52, 53] and large follicles [11] in bovine animals. These data are consistent with a stimulatory effect of n-3 PUFAs on GC proliferation, which is the crucial step involved in the increase in size of the entire follicle. Indeed, an increase in follicle numbers corresponds to increase in follicles that are detectable by ultrasonographic examination $(>2-3 \mathrm{~mm}$ ). The increase of follicles of this size is a consequence of follicles < $2 \mathrm{~mm}$ growth and of the proliferation of their GCs.

\section{DHA increased in vitro granulosa cell steroidogenesis}

With regard to steroidogenesis, we reported here that DHA increased secretion of both progesterone and estradiol. This finding is consistent with increases in the protein expression level of the steroidogenic enzymes, HSD3B1, CYP11A1 and of the carrier StAR that we observed. Indeed, StAR protein is essential for the initial and rate-limiting step in steroid biosynthesis, namely transfer of hydrophobic cholesterol from the outer mitochondrial membrane to the inner mitochondrial membrane (reviewed in [54]), the location of another enzyme crucial to steroid biosynthesis, CYP11A1. This enzyme converts cholesterol into pregnenolone [55]. The HSD3B1 enzyme is a required step in the conversion of pregnenolone into progesterone [56] or in theca cells to further obtain androstenedione [57], the latter being a necessary precursor in estradiol synthesis. Moreover, such stimulating effects of n-3 PUFAs on steroidogenesis have already been described for ovine GCs in vitro, involving both progesterone and estradiol secretion [51]. The increase in progesterone and estradiol observed after DHA treatment is also consistent with our previous results, which showed a stimulatory effect of DHA on progesterone secretion from bovine cumulus cells, originating from GCs [19]. N-3 PUFAs have also been shown to increase progesterone secretion from ovine theca cells in vitro [58] and follicular fluid progesterone concentration (from follicles $4-7 \mathrm{~mm}$ diameter) in vivo, in ewes fed with a n-3 PUFA-enriched diet [51]. Furthermore, in agreement with the increase in StAR protein level measured in the present study, Waters et al. previously showed that a n-3 PUFA-enriched diet led to increased StAR gene expression in another bovine reproductive compartment, the endometrium [59]. In mouse Leydig tumor cells, inhibition of PTGS2 activity (an enzyme required for prostaglandin biosynthesis) is known to facilitate cAMP-induced steroidogenesis via increased StAR protein expression [60]. N-3 PUFAs are known to be potent inhibitors of PTGS2 activity [61]; this may explain the increase in StAR protein expression reported in the present study, following DHA treatment of GCs. The increased estradiol effect observed after DHA treatment indicates that DHA might also affect cytochrome $\mathrm{P} 450$ aromatase and/or $17 \beta$-HSD protein expression levels, as both of these enzymes are necessary for conversion of androstenedione (supplied in our culture media) to estradiol [62]. However, this hypothesis would require further investigation. Finally, examination of steroidogenic enzyme activities would clarify whether DHA affects expression levels only or also the activities of these enzymes.

\section{DHA mechanisms of action through FFAR4}

For the first time, we showed in the present study that FFAR4 is expressed in bovine granulosa cells. To our knowledge, granulosa expression of FFAR4 has not yet been reported in other species. Only a few published papers have reported FFAR4 expression in bovine tissues, namely adipose tissue $[63,64]$. In other species, FFAR4 is expressed in adipose tissue, spleen and intestine in pigs [65], while in human and rodents, its expression is more widely reported in additional tissues (immune cells, pancreatic cells, lung, muscle, liver and placenta) [42, 66-69]. We demonstrated here that FFAR4 is localized in the vicinity of the cellular membrane in GCs, as expected for a $G$ protein-coupled receptor. This expression of FFAR4 in bovine GCs indicates that long chain fatty acids, including DHA, could act on GCs, at least in part, via this receptor. However, it should be noted that not all cultured GCs were shown to express FFAR4.

Activation of FFAR4 by TUG-891 (1 and $50 \mu \mathrm{M})$ mirrored the effect of DHA on GC proliferation, but not on progesterone and estradiol secretion, suggesting that DHA effects on cell proliferation could occur through FFAR4 activation. Indeed, TUG-891 is a specific and potent agonist of FFAR4 [41, 70]. Thus, the effects observed after TUG-891 treatment could be related to FFAR4 activation. It has already been reported that DHA could exert effects through FFAR4 stimulation in adipocytes [71], in macrophages [72] or in cardia cells [73]. Of note, a linear dose response was not reported in the present study, notably concerning GC proliferation (DHA $20 \mu \mathrm{M}$ ). This observation could suggest that the DHA dose response followed a U-shaped (for example) response pattern [74]. It is also possible that, at higher concentration, other DHA mechanisms could occur, potentially counteracting the FFAR4 effect on proliferation.

Moreover, several effects, such as the ability of DHA to inhibit responsiveness of macrophages to endotoxin, inhibition of I $\mathrm{kB}$ kinase phosphorylation, I $\mathrm{kB}$ phosphorylation and degradation, and inhibition of production of TNF, IL- 6 and MCP-1, that have already been demonstrated, were abolished in FFAR4 knockdown cells [28, 75]. In our study, we observed an increase in MAPK14 phosphorylation in GCs after 
DHA supplementation (10 and $50 \mu \mathrm{M})$, and a similar increase after TUG-891 treatment (1, 10 and $50 \mu \mathrm{M})$. As shown in the published literature, MAPK14 (p38 MAPK) may be involved in follicle stimulating hormone (FSH)-induced estradiol secretion in rat and mouse GCs [37, 38], but was also demonstrated to be involved in GC proliferation in a culture model of hamster pre-antral follicles stimulated with transforming growth factor $\beta 1$ (TGF $\beta 1$ ) [76]. Thus, these results suggest that FFAR4 activation leads to the activation of this MAPK14 signaling pathway, which might play a role in DHA effects on bovine GC proliferation. However, additional experiments would be needed to demonstrate that DHA could activate FFAR4 in bovine GCs, involving investigation of, for example, plasmid transfection, FFAR4 overexpression and inhibition, and intracellular calcium measurement.

No effect of TUG-891 treatment was reported on GC steroidogenesis, suggesting that DHA effects on progesterone and estradiol secretion are independent of FFAR4 activation. Several other mechanisms of action have already been proposed for DHA: modification of cellular membrane lipid composition (fluidity, raft formation); regulation of eicosanoid production (for example, prostaglandins and leukotrienes); transcription factor expression (PPARG and SREBF1, for example) or signaling pathways, such as $\mathrm{NF}_{\kappa} \mathrm{B}[26,28,30]$. In this study, we evidenced a significant increase in cellular DHA level from total lipids after $1 \mu \mathrm{M}, 10 \mu \mathrm{M}$ and $50 \mu \mathrm{M}$ DHA treatment. It is thus possible that DHA affected steroidogenesis by one of these mechanisms and not by activating FFAR4.

The study of candidate gene expression that was performed here showed no modification of canonical genes (PPARG, PPARA, SREBF1) following DHA treatment, except for PPARA with the highest DHA dose used, DHA50 $\mu \mathrm{M}$. Similar absence of effects on PPARG have already been reported in other studies, as in this study [77]. Nevertheless, TUG-891 treatment has already been reported to modify PPARG transcription after several days of culture in 3T3L1 [71]. In this study, we analyzed GC gene expression after $8 \mathrm{~h}$ of TUG-891 stimulation, which might be too brief a period to enable transcription modifications to occur immediately after FFAR4 stimulation. The only differences observed in gene expression are upregulations of GPX4 (glutathione peroxidase 4), $N F K B$ (nuclear factor kappa B) and PPARA (peroxisome proliferator-activated receptor alpha) expression after TUG-891 treatment $(10 \mu \mathrm{M})$. GPX4 is a phospholipid hydroperoxidase that protects cells against membrane lipid peroxidation. Such a mechanism has already been described for DHA in murine hippocampal cells [78]. By increasing GPX4 expression, DHA is able to protect the cell from oxidative damage resulting of non-enzymatic peroxidation of membrane phospholipids. It is possible that this mechanism is associated with FFAR4 activation, as we found a similar increase in GPX4 expression after TUG-891 treatment. DHA is able to bind PPARG and $P P A R A$ and can consequently increase insulin sensitivity [26]. Through binding to PPARG, DHA could inhibit activation of $\mathrm{NF \kappa B}$, a key transcription factor involved in inflammatory pathways [26]. Moreover, the inhibitory effect of DHA on $N F k B$ can also occur via the FA receptor FFAR4 [28]. The increased $N F k B$ mRNA expression reported after DHA $50 \mu \mathrm{M}$ and TUG $10 \mu \mathrm{M}$ in the present study is thus surprising and $\mathrm{NF}_{K} \mathrm{~B}$ activation, which was not investigated in the present study, should be studied.

Overall, despite functional differences between DHAtreated and control GCs, there were no huge changes in gene expression. In order to further investigate the effects and mechanisms of action of FFAR4 activation, experiments involving primary GC culture should be replaced by those involving GC line cultures; such cultures would enable FFAR4 overexpression and inactivation, while maintaining a GC phenotype. It is also possible that a global transcriptomic approach should be envisioned after DHA treatment in order to have a broad picture of the potential mechanisms involved. Indeed, the investigation of other genes, such as PTGS2, might have shown differences that could explain StAR regulation, for example.

Of note, the culture system used in this experiment is serum free and prevent the differentiation of granulosa cells generally occurring after about $15 \mathrm{~h}$ culture. It also enable to treat cells with the precise concentrations of DHA (which would be already present in culture medium if we had used serum). In the culture system used in the present paper, GC are maintaining a round shape even when platted, at least till $48 \mathrm{~h}$ culture (the latest endpoints in this paper), and not a fibroblastic-like shape, meaning they did not differentiate as much as when serum is used. On the other hand, this culture system also presented some disadvantages. Indeed, primary cell cultures require freshly isolating GCs for each culture, and therefore they can exhibit huge variation in response to treatment, depending on the batch of ovaries used. In this context, the use of a high number of independent culture can be compulsory, as in the present work. Moreover, in this culture system, in order to be able to set up endpoints before $48 \mathrm{~h}$ culture, we chose to treat cells at the beginning of the culture, meaning that both platted and non-platted cells were treated. A similar number of living cells is cultured in each well, with a varying proportion of dead cells (assessed by trypan blue staining and cell counting). Concerning proliferation assay, as floating cells are removed before the assay, only thymidine incorporated in platted cells is 
measured (most of floating cells being dead cells in our cell culture system). Concerning data on steroidogenesis, steroid secreted in the culture medium by both platted and non-platted cells during the cell culture are measured after $48 \mathrm{~h}$. Steroid concentration are normalized by protein concentration in each well, meaning by protein amount of platted cells only. We estimated that the proportion of platted cells to viable floating cells is the same in each well for a specific batch of cells. This normalization might biased the steroid results as the concentration of steroid for a viable amount of cells might be slightly overestimated due to the normalization taking into account only platted cells. Nevertheless, we believe that this normalization would not affect differences observed between conditions.

\section{Conclusions}

The present study reported that DHA treatment during in vitro culture increased granulosa cell proliferation and PCNA expression level, suggesting an effect of this n-3 PUFA on DNA synthesis. This effect is relevant with the increase in ovarian follicular population observed after in vivo n-3 enriched diet supplementation of dairy cows. DHA supplementation also increased progesterone and estradiol secretion, together with the protein expression level of the steroidogenic enzymes HSD3B1, CYP11A1 and the cholesterol transporter StAR. Such increase in progesterone level is also reported after in vivo n-3 enriched diet supplementation of dairy cows. These effects on granulosa cell function could thus be related to the improved reproduction observed after n-3 enriched diet supplementation. TUG-891, a FFAR4 agonist, showed similar effects to DHA on GC proliferation and on MAPK14 phosphorylation, but had no effect on steroidogenesis. These data indicate that DHA might act on GC proliferation through FFAR4 activation, which, in turn, leads to MAPK14 phosphorylation. Nevertheless, FFAR4 activation by DHA remains to be demonstrated in bovine GCs. Other potential mechanisms of DHA action on steroidogenesis should be investigated, as our hypothesis of FFAR4-mediated effects on steroidogenesis was not verified.

\section{Additional files}

Additional file 1: Figure S1. Control of customized free fatty acid receptor 4 (FFAR4) antibody specificity. Protein extracts from bovine lung tissue were separated by electrophoresis on 4-12\% (w:v) SDSpolyacrylamide gel. After electrotransfer to nitrocellulose membranes, the proteins were probed with anti-FFAR4 antibody $(0.95 \mu \mathrm{g} / \mathrm{mL}$, customized FFAR4 rabbit antibody, Agro-Bio), which was pre-incubated for $15 \mathrm{~min}$ with different concentrations of the bovine specific peptide (Agro-Bio) used to produce the antibody (from 0 to $2.5 \mu \mathrm{g} / \mathrm{mL}$ ). The blots were stripped and re-probed with antibodies against vinculin (VCL) used as the loading control. (TIF $93 \mathrm{~kb}$ )
Additional file 2: Table S1. Characteristics of primary antibodies used for western blotting and / or immunohistochemistry or immunofluorescence. (DOCX $16 \mathrm{~kb}$ )

Additional file 3: Figure S2. Experiment design of the study. * Some experiments enabled to measure both progesterone and estradiol in supernatants of the same 96-well dishes. (TIF $342 \mathrm{~kb}$ )

Additional file 4: Figure S3. Gene expression of (A) free fatty acid receptor 1 (FFAR1) and (B) free fatty acid receptor 4 (FFAR4) in bovine ovarian cells. Total mRNA was extracted from the ovarian cortex (CX), thecal cells (TH), granulosa cells (GC) and cumulus cells (CC). Total mRNA was then reverse-transcribed and real-time RT-PCR was performed. The geometric mean of two housekeeping genes (RPL19- ribosomal protein L19 and RPS9- ribosomal protein S9) was used to normalize gene expression. Results of 2 to 4 independent samples are presented as means \pm SEM. Bars with different superscripts are significantly different $(p<0.05)$. (TIF $59 \mathrm{~kb}$ )

Additional file 5: Figure S4. Expression and localization of free fatty acid receptor 4 (FFAR4) in bovine granulosa cells by immunofluorescence with a commercial antibody against human FFAR4. Immunofluorescence was performed on granulosa cells (GC) after in vitro culture. Briefly, recovered GCs after follicle puncture and GC washing were incubated in serum-free modified McCoy's 5A medium $\left(2.5 \times 10^{5}\right.$ viable cells/well on a 8-well chamber slide (Lab-Tek ${ }^{\oplus}$ Nunc) for $48 \mathrm{~h}$. Cultures were performed in a water-saturated atmosphere containing $5 \% \mathrm{CO}_{2}$ in air at $38^{\circ} \mathrm{C}$. FFAR4 (green fluorescence) was immunodetected in GC (commercial human FFAR4 rabbit antibody, Aviva Systems Biology, Clinisciences, Nanterre, France) with a similar protocol to the protocol used with the customized anti-FFAR4 antibody. The commercial anti- FFAR4 antibody was produced by using a peptide from the FFAR4 human c-terminal region, which shares $89 \%$ identity (Protein BLAST ${ }^{\oplus}$ result on NCBI website) with the Bos taurus FFAR4 (Accession number: NP_001315586.1) and no identity with other amino acid sequences of bovine proteome. Rabbit lgG was used as the control with the same secondary antibody as for FFAR4 detection. Nuclei were stained with Hoechst 33,258 (blue fluorescence). Fluorescence was observed under a Zeiss confocal microscope LSM700 (Carl Zeiss Microscopy GmbH, Munich, Germany) using an oil 63× objective and the appropriate filters. The images were captured using Zen 2012 software (black edition version 8.0, Carl Zeiss Microscopy GmbH). The picture framed in red is a magnification of the area framed in red from the original image. Bars $=10 \mu \mathrm{m}$. (TIF $132 \mathrm{~kb}$ )

Additional file 6: Figure S6. Protein expression of (A) proliferating cell nuclear antigen (PCNA), (B) hydroxy-delta-5-steroid dehydrogenase, 3 beta- and steroid delta-isomerase 1 (HSD3B1), (C) steroidogenic acute regulatory protein (StAR) and (D) cytochrome P450 family 11 subfamily $A$ member 1 (CYP11A1) after $15 \mathrm{~h}$ treatment with DHA. Effects of DHA treatment on protein levels were assessed in bovine granulosa cells after $15 \mathrm{~h}$ culture in enriched McCoy's 5A media in presence or absence of DHA 10 or $20 \mu \mathrm{M}$. The chemical DMSO alone (1/2000) was used as a negative control due to its solvent activity on DHA. Protein extracts were separated by electrophoresis on 4-12\% (w:v) SDS-polyacrylamide gel. After electrotransfer to nitrocellulose membranes, the proteins were probed with anti-PCNA (A), anti-HSD3B1 (B), anti-StAR (C) or antiCYP11A1 (D) antibodies. The blots were stripped and re-probed with antibodies against Vinculin (VCL). The blots presented are representative of the quantification reported in Fig. 6. (TIF $180 \mathrm{~kb}$ )

Additional file 7: Figure S5. Signaling pathways in bovine granulosa cells after treatment with other concentrations of DHA $(50 \mu \mathrm{M})$ or TUG$891(10$ and $50 \mu \mathrm{M})$. Effects of DHA or TUG-891 on phosphorylation of (A) mitogen-activated protein kinase 14 (MAPK14), (B) AMP-activated protein kinasea (AMPKa) and (C) mitogen-activated protein kinase 1/3 (MAPK1/3) signaling pathways were assessed in bovine granulosa cells cultured for $15 \mathrm{~h}$ in enriched McCoy's 5A media with $50 \mu \mathrm{M}$ DHA or with 10 or 50 MM TUG-891, as described in Material and Method section for 5, 10, 30 and $60 \mathrm{~min}$. Protein extracts were separated by electrophoresis on 4-12\% 
(w:v) SDS-polyacrylamide gel. After electrotransfer to nitrocellulose membranes, the proteins were probed with anti-phosphorylated (p-)MAPK14 (A), anti-p-AMPKa (B) or anti-p-MAPK1/3 (C) antibodies. The blots were stripped and re-probed with antibodies against MAPK14, AMPKa, or MAPK $1 / 3$, respectively. Bands on the blots were quantified. Results of four independent experiments are presented as the ratio of p-protein to total protein, normalized by the ratio observed in control at each time and expressed as mean \pm SEM, with time 0 min being equal to 1 (for reference). Bars with different superscripts are significantly different $(p<0.05)$. (TIF $99 \mathrm{~kb}$ )

Additional file 8: Figure S7. Signaling pathways in bovine granulosa cells after DHA or TUG-891 treatment. Effects of DHA or TUG-891 on phosphorylation of (A) mitogen-activated protein kinase 14 (MAPK14), (B) AMP-activated protein kinasea (AMPKa) and (C) protein kinase B (Akt) signaling pathways were assessed in bovine granulosa cells cultured for $15 \mathrm{~h}$ in enriched McCoy's 5A media with $10 \mu \mathrm{M}$ DHA or 1 MM TUG-891, as described in Material and Method section for 5, 10, 30 and 60 min. Protein extracts were separated by electrophoresis on 4-12\% (w:v) SDSpolyacrylamide gel. After electrotransfer to nitrocellulose membranes, the proteins were probed with anti-phosphorylated (p-) MAPK14 (A), anti-pAMPKa (B) or anti-p-AKT1/2/3 (C) antibodies. The blots were stripped and re-probed with antibodies against MAPK14, AMPKa or Akt, respectively. The blots presented are representative of the quantification reported in Fig. 8. (TIF $228 \mathrm{~kb}$ )

\section{Abbreviations}

Akt: Protein kinase B; ALA: Alpha-linolenic acid; AMPKa: AMP-activated protein kinasea; BSA: Bovine serum albumin; CYP11A1: Cytochrome P450 family 11 subfamily A member 1; DAB: Diaminobenzidine tetrahydrochloride dehydrate; DHA: Docosahexaenoic acid; DMSO: Dimethyl sulfoxide; DNA: Deoxyribonucleic acid; ELISA: Enzyme-linked immunosorbent assay; EPA: Eicosapentaenoic acid; FA: Fatty acids; FAME: Fatty acid methyl ester FFAR1: Free fatty acid membrane receptor 1; FFAR4: Free fatty acid membrane receptor 4; GC: Granulosa cells; GLUT1: Glucose Transporter Type 1; GPX4: Glutathione peroxidase 4; HRP: Horseradish peroxidase; HSD3B1: Hydroxy-delta-5-steroid dehydrogenase, 3 beta- and steroid deltaisomerase 1; IgG: Immunoglobulin G; IL-1 $\beta$ : Interleukine 1 beta; IL6: Interleukine 6; IL-8: Interleukine 8; IkB: I kappa B; LDL: Low density lipoprotein; MAP K14: Mitogen-Activated Protein Kinase 14; MAPK1/ 3: Mitogen-Activated Protein Kinase 1/3; MCP-1: Monocyte Chemoattractant Protein-1; NFDMP: Non-fat dry milk powder; NFkB: Nuclear factor kappa B PBS: Phosphate buffered saline; PCNA: Proliferating cell nuclear antigen; PCR: Polymerase chain reaction; PGF2a: Prostaglandin F2 alpha; PPARs: Peroxisome proliferator-activated receptors; PTGS2: ProstaglandinEndoperoxide Synthase 2; PUFA: Polyunsaturated fatty acid; RNA: Ribonucleic acid; RPL19: Ribosomal protein L19; RPS9: Ribosomal protein S9; SEM: Standard error of the mean; SREBF1: Sterol Regulatory Element Binding Transcription Factor 1; StAR: Steroidogenic acute regulatory protein; TBS: Trisbuffer saline; TGF $\beta 1$ : Transforming growth factor beta1; TNF: Tumor necrosis factor

\section{Acknowledgements}

We would like to thank the technical staff of the research (PRC) unit in INRA Val de Loire Centre (Albert Arnould and Thierry Delpuech) for collecting the ovaries.

\section{Funding}

The Institut National de la Recherche Agronomique (INRA) and « Région Centre-Val de Loire » subvention project BOVOMEGA3 financially supported this work.

\section{Availability of data and materials}

The datasets used and/or analysed during the current study are available from the corresponding author upon reasonable request.

\section{Authors' contributions}

$A D$ and MD performed the experiments and analyses in this study. SU helped with preparation of the manuscript. VM performed immunofluorescence and immunohistochemistry in the study. SE and VM were involved in data analysis and were major contributors to writing the manuscript. All authors read and approved the final manuscript.

Ethics approval and consent to participate

Not applicable.

\section{Competing interests}

The authors declare that they have no competing interests.

\section{Publisher's Note}

Springer Nature remains neutral with regard to jurisdictional claims in published maps and institutional affiliations.

Received: 9 February 2018 Accepted: 18 April 2018

Published online: 26 April 2018

\section{References}

1. Siriwardhana N, Kalupahana NS, Moustaid-Moussa N, Se-Kwon K. Chapter 13 - health benefits of $n-3$ polyunsaturated fatty acids: Eicosapentaenoic acid and docosahexaenoic acid. In: Adv Food Nutr Res. Vol. volume 65: academic press; 2012. p. 211-22.

2. Plourde M, Cunnane SC. Extremely limited synthesis of long chain polyunsaturates in adults: implications for their dietary essentiality and use as supplements. Appl Physiol Nutr Metab. 2007:32(4):619-34.

3. Baker EJ, Miles EA, Burdge GC, Yaqoob P, Calder PC. Metabolism and functional effects of plant-derived omega-3 fatty acids in humans. Prog Lipid Res. 2016;64:30-56.

4. Simopoulos AP. Omega-3 fatty acids in inflammation and autoimmune diseases. J Am Coll Nutr. 2002;21(6):495-505.

5. Deckelbaum RJ, Torrejon C. The omega-3 fatty acid nutritional landscape: health benefits and sources. J Nutr. 2012:142(3):587S-91S

6. Calder PC. Functional roles of fatty acids and their effects on human health. J Parenter Enter Nutr. 2015:39(1 suppl):18S-32S.

7. Santos JE, Bilby TR, Thatcher WW, Staples CR, Silvestre FT. Long chain fatty acids of diet as factors influencing reproduction in cattle. Reprod Domest Anim. 2008;43(Suppl 2):23-30.

8. Gulliver $C E$, Friend MA, King BJ, Clayton EH. The role of omega-3 polyunsaturated fatty acids in reproduction of sheep and cattle. Anim Reprod Sci. 2012;131(1-2):9-22.

9. Ambrose DJ, Kastelic JP, Corbett R, Pitney PA, Petit HV, Small JA, Zalkovic P. Lower pregnancy losses in lactating dairy cows fed a diet enriched in alpha-linolenic acid. J Dairy Sci. 2006;89(8):3066-74.

10. Dirandeh E, Towhidi A, Zeinoaldini S, Ganjkhanlou M, Ansari Pirsaraei Z, Fouladi-Nashta A. Effects of different polyunsaturated fatty acid supplementations during the postpartum periods of early lactating dairy cows on milk yield, metabolic responses, and reproductive performances. J Anim Sci. 2013;91(2):713-21.

11. Elis S, Freret $S$, Desmarchais A, Maillard V, Cognié J, Briant E, Touzé J-L, Dupont $M$, Faverdin P, et al. Effect of a long chain n-3 PUFA-enriched diet on production and reproduction variables in Holstein dairy cows. Anim Reprod Sci. 2016;164:121-32.

12. Mattos R, Staples CR, Arteche A, Wiltbank MC, Diaz FJ, Jenkins TC, Thatcher WW. The effects of feeding fish oil on uterine secretion of PGF2alpha, milk composition, and metabolic status of periparturient Holstein cows. J Dairy Sci. 2004:87(4):921-32.

13. Caldari-Torres C, Rodriguez-Sallaberry C, Greene ES, Badinga L. Differential effects of n-3 and n-6 fatty acids on prostaglandin F2[alpha] production by bovine endometrial cells. J Dairy Sci. 2006;89(3):971-7.

14. Mattos R, Staples CR, Williams J, Amorocho A, McGuire MA. Uterine, ovarian, and production responses of lactating dairy cows to increasing dietary concentrations of menhaden fish meal. J Dairy Sci. 2002:85(4):755-64.

15. Dirandeh E, Towhidi A, Pirsaraei ZA, Hashemi FA, Ganjkhanlou M, Zeinoaldini S, Roodbari AR, Saberifar T, Petit HV. Plasma concentrations of PGFM and uterine and ovarian responses in early lactation dairy cows fed omega-3 and omega-6 fatty acids. Theriogenology. 2013;80(2):131-7.

16. Moallem U, Shafran A, Zachut M, Dekel I, Portnick Y, Arieli A. Dietary alphalinolenic acid from flaxseed oil improved folliculogenesis and IVF performance in dairy cows, similar to eicosapentaenoic and docosahexaenoic acids from fish oil. Reproduction. 2013;146(6):603-14.

17. Zachut M, Dekel I, Lehrer $H$, Arieli A, Arav A, Livshitz L, Yakoby S, Moallem U. Effects of dietary fats differing in n-6:n-3 ratio fed to high-yielding dairy 
cows on fatty acid composition of ovarian compartments, follicular status, and oocyte quality. J Dairy Sci. 2010;93(2):529-45.

18. Marei WF, Wathes DC, Fouladi-Nashta AA. The effect of linolenic acid on bovine oocyte maturation and development. Biol Reprod. 2009; 81(6):1064-72.

19. Oseikria M, Elis S, Maillard V, Corbin E, Uzbekova S. N-3 polyunsaturated fatty acid DHA during IVM affected oocyte developmental competence in cattle. Theriogenology. 2016;85:1625-34.

20. Petit HV, Twagiramungu $\mathrm{H}$. Conception rate and reproductive function of dairy cows fed different fat sources. Theriogenology. 2006;66(5):1316-24.

21. Childs S, Carter F, Lynch CO, Sreenan JM, Lonergan P, Hennessy AA, Kenny DA. Embryo yield and quality following dietary supplementation of beef heifers with n-3 polyunsaturated fatty acids (PUFA). Theriogenology. 2008; 70(6):992-1003.

22. Sinedino LDP, Honda PM, Souza LRL, Lock AL, Boland MP, Staples CR, Thatcher WW, Santos JEP. Effects of supplementation with docosahexaenoic acid on reproduction of dairy cows. Reproduction. 2017;153(5):707-23.

23. Ponter AA, Guyader-Joly C, Nuttinck F, Grimard B, Humblot P. Oocyte and embryo production and quality after OPU-IVF in dairy heifers given diets varying in their n-6/n-3 fatty acid ratio. Theriogenology. 2012;78(3):632-45.

24. Hutchinson IA, Hennessy AA, Waters SM, Dewhurst RJ, Evans ACO, Lonergan P, Butler ST. Effect of supplementation with different fat sources on the mechanisms involved in reproductive performance in lactating dairy cattle. Theriogenology. 2012;78(1):12-27.

25. Riediger ND, Othman RA, Suh M, Moghadasian MH. A systemic review of the roles of n-3 fatty acids in health and disease. J Am Diet Assoc. 2009; 109(4):668-79.

26. Calder PC. Mechanisms of action of (n-3) fatty acids. J Nutr. 2012;142(3): 592S-9S.

27. Calder PC. Fatty acids and inflammation: the cutting edge between food and pharma. Eur J Pharmacol. 2011;668(Suppl 1):S50-8

28. Calder PC. Marine omega-3 fatty acids and inflammatory processes: effects, mechanisms and clinical relevance. Biochim et Biophys Acta (BBA) Molecular and Cell Biology of Lipids. 2015;1851(4):469-84.

29. Bagga D, Wang L, Farias-Eisner R, Glaspy JA, Reddy ST. Differential effects of prostaglandin derived from $\omega-6$ and $\omega-3$ polyunsaturated fatty acids on COX-2 expression and IL-6 secretion. Proc Natl Acad Sci U S A. 2003;100(4):1751-6.

30. Shaikh SR. Biophysical and biochemical mechanisms by which dietary N-3 polyunsaturated fatty acids from fish oil disrupt membrane lipid rafts. J Nutr Biochem. 2012;23(2):101-5.

31. Miyamoto J, Hasegawa S, Kasubuchi M, Ichimura A, Nakajima A, Kimura I. Nutritional signaling via free fatty acid receptors. Int J Mol Sci. 2016;17(4):450.

32. Prihandoko R, Alvarez-Curto E, Hudson BD, Butcher AJ, Ulven T, Miller AM, Tobin AB, Milligan G. Distinct phosphorylation clusters determine the signaling outcome of free fatty acid receptor $4 / \mathrm{G}$ protein-coupled receptor 120. Mol Pharmacol. 2016;89(5):505-20.

33. Gao B, Huang Q, Jie Q, Lu WG, Wang L, Li XJ, Sun Z, Hu YQ, Chen L, et al. GPR120: a bi-potential mediator to modulate the osteogenic and adipogenic differentiation of BMMSCs. Sci Rep. 2015;5:14080.

34. Gómez Bl, Gifford CA, Hallford DM, Hernandez Gifford JA. Protein kinase B is required for follicle-stimulating hormone mediated beta-catenin accumulation and estradiol production in granulosa cells of cattle. Anim Reprod Sci. 2015;163:97-104.

35. Silva JM, Hamel M, Sahmi M, Price CA. Control of oestradiol secretion and of cytochrome P450 aromatase messenger ribonucleic acid accumulation by FSH involves different intracellular pathways in oestrogenic bovine granulosa cells in vitro. Reproduction. 2006;132(6):909-17.

36. Ryan $\mathrm{KE}$, Glister $\mathrm{C}$, Lonergan $\mathrm{P}$, Martin F, Knight $\mathrm{PG}$, Evans $\mathrm{AC}$. Functional significance of the signal transduction pathways Akt and Erk in ovarian follicles: in vitro and in vivo studies in cattle and sheep. J Ovarian Res. 2008; 1(1):2

37. Du XH, Zhou XL, Cao R, Xiao P, Teng Y, Ning CB, Liu HL. FSH-induced p38MAPK-mediated dephosphorylation at serine 727 of the signal transducer and activator of transcription 1 decreases Cyp1b1 expression in mouse granulosa cells. Cell Signal. 2015;27(1):6-14.

38. Inagaki K, Otsuka F, Miyoshi T, Yamashita M, Takahashi M, Goto J, Suzuki J, Makino H. p38-mitogen-activated protein kinase stimulated steroidogenesis in granulosa cell-oocyte cocultures: role of bone morphogenetic proteins 2 and 4. Endocrinology. 2009;150(4):1921-30.

39. Abughazaleh AA, Potu RB, Ibrahim S. Short communication: the effect of substituting fish oil in dairy cow diets with docosahexaenoic acid- micro algae on milk composition and fatty acids profile. J Dairy Sci. 2009;92(12):6156-9.

40. Boeckaert C, Vlaeminck B, Dijkstra J, Issa-Zacharia A, Van Nespen T, Van Straalen W, Fievez V. Effect of dietary starch or micro algae supplementation on rumen fermentation and milk fatty acid composition of dairy cows. J Dairy Sci. 2008:91(12):4714-27.

41. Hudson BD, Shimpukade B, Mackenzie AE, Butcher AJ, Pediani JD, Christiansen $E$, Heathcote $H$, Tobin AB, Ulven T, et al. The pharmacology of TUG-891, a potent and selective agonist of the free fatty acid receptor 4 (FFA4/GPR120), demonstrates both potential opportunity and possible challenges to therapeutic agonism. Mol Pharmacol. 2013;84(5):710-25.

42. Hirasawa A, Tsumaya K, Awaji T, Katsuma S, Adachi T, Yamada M, Sugimoto Y, Miyazaki S, Tsujimoto G. Free fatty acids regulate gut incretin glucagonlike peptide-1 secretion through GPR120. Nat Med. 2005;11(1):90-4.

43. Tosca L, Chabrolle C, Uzbekova S, Dupont J. Effects of metformin on bovine granulosa cells steroidogenesis: possible involvement of adenosine 5 ' monophosphate-activated protein kinase (AMPK). Biol Reprod. 2007;76(3):368-78.

44. Canepa S, Laine AB, A., Fagu C, Flon C, Monniaux D: Validation d'une methode immunoenzymatique pour le dosage de la progesterone dans le plasma des ovins et des bovins. Les Cahiers Techniques de L'INRA 2008; 64:19-30.

45. Lefils J, Géloën A, Vidal H, Lagarde M, Bernoud-Hubac N. Dietary DHA: time course of tissue uptake and effects on cytokine secretion in mice. Br J Nutr. 2010;104(9):1304-12

46. Hothorn T, Bretz F, Westfall P. Simultaneous inference in general parametric models. Biom J. 2008;50(3):346-63.

47. Wheeler B: ImPerm: Permutation tests for linear models. 2010.

48. Konietschke F, Placzek M, Schaarschmidt F, Hothorn LA. Nparcomp: an R software package for nonparametric multiple comparisons and simultaneous confidence intervals. J Stat Softw. 2015;64(9):1-17.

49. R_Core_Team. R: a language and environment for statistical computing. Vienna: R-project; 2015.

50. Choe KN, Moldovan G-L. Forging ahead through darkness: PCNA, still the principal conductor at the replication fork. Mol Cell. 2017:65(3):380-92.

51. Wonnacott KE, Kwong WY, Hughes J, Salter AM, Lea RG, Garnsworthy PC, Sinclair KD. Dietary omega-3 and -6 polyunsaturated fatty acids affect the composition and development of sheep granulosa cells, oocytes and embryos. Reproduction. 2010:139(1):57-69.

52. Moussavi ARH, Gilbert RO, Overton TR, Bauman DE, Butler WR. Effects of feeding fish meal and $\mathrm{n}-3$ fatty acids on ovarian and uterine responses in early lactating dairy cows. J Dairy Sci. 2007;90(1):145-54.

53. Robinson RS, Pushpakumara PG, Cheng Z, Peters AR, Abayasekara DR, Wathes DC. Effects of dietary polyunsaturated fatty acids on ovarian and uterine function in lactating dairy cows. Reproduction. 2002;124(1):119-31.

54. Stocco DM, Zhao AH, Tu LN, Morohaku K, Selvaraj V. A brief history of the search for the protein(s) involved in the acute regulation of steroidogenesis. Mol Cell Endocrinol. 2017:441:7-16.

55. Rodgers RJ. Steroidogenic cytochrome P450 enzymes and ovarian steroidogenesis. Reprod Fertil Dev. 1990;2(2):153-63.

56. Bao B, Garverick HA. Expression of steroidogenic enzyme and gonadotropin receptor genes in bovine follicles during ovarian follicular waves: a review. $J$ Anim Sci. 1998;76(7):1903-21.

57. Benkert AR, Young M, Robinson D, Hendrickson C, Lee PA, Strauss KA. Severe Salt-Losing 3ß-Hydroxysteroid Dehydrogenase Deficiency: Treatment and Outcomes of HSD3B2 c.35G\&gt;A Homozygotes. J Clinical Endocrinol Metabol. 2015;100(8):E1105-15.

58. Hughes J, Kwong WY, Li D, Salter AM, Lea RG, Sinclair KD. Effects of omega3 and -6 polyunsaturated fatty acids on ovine follicular cell steroidogenesis, embryo development and molecular markers of fatty acid metabolism. Reproduction. 2011;141(1):105-18.

59. Waters SM, Coyne GS, Kenny DA, MacHugh DE, Morris DG. Dietary n-3 polyunsaturated fatty acid supplementation alters the expression of genes involved in the control of fertility in the bovine uterine endometrium. Physiol Genomics. 2012;44(18):878-88.

60. Wang $X$, Dyson MT, Jo Y, Stocco DM. Inhibition of Cyclooxygenase-2 activity enhances steroidogenesis and steroidogenic acute regulatory gene expression in MA-10 mouse Leydig cells. Endocrinology. 2003; 144(8):3368-75.

61. Ringbom T, Huss U, Stenholm Å, Flock S, Skattebøl L, Perera P, Bohlin L. COX-2 inhibitory effects of naturally occurring and modified fatty acids. J Nat Prod. 2001;64(6):745-9. 
62. Pavone ME, Bulun SE. Aromatase inhibitors for the treatment of endometriosis: a review. Fertil Steril. 2012;98(6):1370-9.

63. Elis S, Desmarchais A, Freret S, Maillard V, Labas V, Cognié J, Briant E, Hivelin C, Dupont J, et al. Effect of a long-chain n-3 polyunsaturated fatty acidenriched diet on adipose tissue lipid profiles and gene expression in Holstein dairy cows. J Dairy Sci. 2016;99(12):10109-27.

64. Agrawal A, Alharthi A, Vailati-Riboni M, Zhou Z, Loor JJ. Expression of fatty acid sensing G-protein coupled receptors in peripartal Holstein cows. J Anim Sci Biotechnol. 2017;8(1):20.

65. Song T, Peng J, Ren J, H-k W, Peng J. Cloning and characterization of spliced variants of the porcine $\mathrm{G}$ protein coupled receptor 120 . Biomed Res Int. 2015;2015:813816.

66. Gotoh C, Hong YH, Iga T, Hishikawa D, Suzuki Y, Song SH, Choi KC, Adachi T, Hirasawa A, et al. The regulation of adipogenesis through GPR120. Biochem Biophys Res Commun. 2007:354(2):591-7.

67. Miyauchi S, Hirasawa A, Iga T, Liu N, Itsubo C, Sadakane K, Hara T, Tsujimoto G. Distribution and regulation of protein expression of the free fatty acid receptor GPR120. Naunyn Schmiedeberg's Arch Pharmacol. 2009;379(4):427-34.

68. Cornall LM, Mathai ML, Hryciw DH, McAinch AJ. Diet-induced obesity upregulates the abundance of GPR43 and GPR120 in a tissue specific manner. Cell Physiol Biochem. 2011;28(5):949-58,

69. Lager S, Ramirez VI, Gaccioli F, Jansson T, Powell TL. Expression and localization of the omega-3 fatty acid receptor GPR120 in human term placenta. Placenta. 2014;35(7):523-5.

70. Shimpukade B, Hudson BD, Hovgaard CK, Milligan G, Ulven T. Discovery of a potent and selective GPR120 agonist. J Med Chem. 2012;55(9):4511-5.

71. Song T, Zhou Y, Peng J, Tao Y-X, Yang Y, Xu T, Peng J, Ren J, Xiang Q, et al. GPR120 promotes adipogenesis through intracellular calcium and extracellular signal-regulated kinase 1/2 signal pathway. Mol Cell Endocrinol. 2016:434:1-13.

72. Anbazhagan AN, Priyamvada S, Gujral T, Bhattacharyya S, Alrefai WA, Dudeja PK, Borthakur A. A novel anti-inflammatory role of GPR120 in intestinal epithelial cells. Am J Physiol Cell Physiol. 2016;310(7):C612-21.

73. Li X, Ballantyne LL, Che X, Mewburn JD, Kang JX, Barkley RM, Murphy RC, Yu $Y$, Funk CD. Endogenously generated Omega-3 fatty acids attenuate vascular inflammation and Neointimal hyperplasia by interaction with free fatty acid receptor 4 in mice. J Am Heart Assoc: Cardiovasc Cerebrovasc Dis. 2015;4(4):e001856.

74. Calabrese EJ, Baldwin LA. U-shaped dose-responses in biology, toxicology, and public health. Annu Rev Public Health. 2001;22:15-33.

75. Oh DY, Talukdar S, Bae EJ, Imamura T, Morinaga H, Fan W, Li P, Lu WJ, Watkins SM, et al. GPR120 is an omega-3 fatty acid receptor mediating potent anti-inflammatory and insulin-sensitizing effects. Cell. 2010;142(5):687-98.

76. Yang P, Roy SK. Transforming growth factor B1 stimulated DNA synthesis in the granulosa cells of preantral follicles: negative interaction with epidermal growth factor. Biol Reprod. 2006;75(1):140-8.

77. Vaidya $\mathrm{H}$, Cheema SK. Arachidonic acid has a dominant effect to regulate lipogenic genes in 3T3-L1 adipocytes compared to omega-3 fatty acids. Food Nutr Res. 2015;59 https://doi.org/10.3402/fnr.v3459.25866.

78. Casañas-Sánchez V, Pérez JA, Fabelo N, Quinto-Alemany D, Díaz ML. Docosahexaenoic (DHA) modulates phospholipid-hydroperoxide glutathione peroxidase (Gpx4) gene expression to ensure self-protection from oxidative damage in hippocampal cells. Front Physiol. 2015;6:203.

\section{Ready to submit your research? Choose BMC and benefit from:}

- fast, convenient online submission

- thorough peer review by experienced researchers in your field

- rapid publication on acceptance

- support for research data, including large and complex data types

- gold Open Access which fosters wider collaboration and increased citations

- maximum visibility for your research: over $100 \mathrm{M}$ website views per year

At BMC, research is always in progress.

Learn more biomedcentral.com/submissions 